\title{
MiniReVIew
}

\section{Normal and Pathologic Soft Tissue Remodeling: Role of the Myofibroblast, with Special Emphasis on Liver and Kidney Fibrosis}

\author{
Alexis Desmoulière, lan A. Darby, and Giulio Gabbiani \\ Groupe de Recherches pour l'Etude du Foie (AD), INSERM E0362, Université Victor Segalen Bordeaux 2, Bordeaux, \\ France; Wound Healing and Microvascular Biology Group (IAD), School of Medical Sciences, RMIT University, \\ Victoria, Australia; and Department of Pathology (GG), Centre Médical Universitaire, Geneva, Switzerland
}

$T$ he retractile and remodeling phenomena accompanying and, in pathologic situations, following the healing of an open wound have attracted the interest of physicians and scientists for many centuries. It has long been assumed that these phenomena depend on extracellular matrix reorganization; however, the demonstration that fibroblastic cells acquire contractile features during the evolution of granulation tissue (for review, see Schürch et al, 1998) has switched the interest from the extracellular to the intracellular compartment. The past 30 years have seen the accumulation of advances in the field of contractile fibroblasts or myofibroblasts that presently appear to be the key cell for the production of granulation tissue remodeling. Myofibroblasts are obviously also producing extracellular matrix components such as collagen and fibronectin, and it has become clearer that granulation tissue remodeling depends on the coordinate activities of intracellular and extracellular molecules. The interactions of these molecules are under the control of microenvironmental factors such as transforming growth factor- $\beta$ (TGF- $\beta$ ) or other cytokines and mechanical stress. The purpose of our review is to summarize recent advances made in this field by several laboratories, with special emphasis on the evolution of fibrotic phenomena in the liver and the kidney.

\section{DOI: 10.1097/01.LAB.0000101911.53973.90}

Received July 21, 2001.

This work was supported in part by the Swiss National Science Foundation (grant no. 31-61.336.00) and a visiting fellowship by the University of Bordeaux 2 (to IAD).

Address reprint requests to: Dr. A. Desmoulière, GREF, INSERM E0362, Université Victor Segalen Bordeaux 2, 146, rue Léo-Saignat, 33076 Bordeaux cedex, France. E-mail: Alexis.Desmouliere@gref.u-bordeaux2.fr

\section{Definition and Cytoskeletal Markers of Myofibroblasts}

Granulation tissue, which allows the replacement of the injured tissue, is mainly characterized by fibroblast proliferation, angiogenesis, and extracellular matrix deposition. Fibroblasts acquire smooth muscle (SM) features characterizing the myofibroblast (for review, see Desmoulière and Gabbiani, 1996; Schürch et al, 1998; Serini and Gabbiani, 1999; Tomasek et al, 2002) that represents the main cellular element present in granulation tissue (Gabbiani, 1998). Myofibroblasts contain cytoplasmic bundles of microfilaments or stress fibers, which with mechanism similar but not identical to those taking place in SM cells, play a role in contraction (Grinnell, 1994, 2000). Myofibroblasts are interconnected by gap junctions and are also connected to the extracellular matrix by a specialized structure called fibronexus, a transmembrane complex involving intracellular microfilaments in continuity with extracellular fibronectin fibers (Eyden, 1993; Singer et al, 1984). More recently, the fibronexus has been assimilated to the mature or supermature focal contact, ie, three-dimensional transcellular structure containing the fibronectin isoform ED-A and $\alpha$-SM actin; these are organized by intracellularly and extracellularly originated forces and play a role in the establishment and modulation of the myofibroblastic phenotype (Dugina et al, 2001). Recently, it has been shown that $\alpha$-SM actin is crucial for focal adhesion maturation in myofibroblasts (Hinz et al, 2003). Furthermore, myofibroblasts are the main cellular type involved in extracellular matrix deposition during tissue repair (Zhang et al, 1994). To replace the damaged tissue, myofibroblasts participate actively in the synthesis of extracellular matrix components such as collagens I and III, tenascin, and fibronectin. Myofibroblasts are also responsible for the synthesis of enzymes involved in matrix degradation. 
Myofibroblasts express different sets of cytoskeletal proteins that represent useful markers of cell differentiation; the study of their expression allows the characterization of fibroblastic phenotypic modifications corresponding to functional changes that take place during physiologic and pathologic repair processes (Sappino et al, 1990; Schmitt-Gräff et al, 1994). The cytoskeleton of eukaryotic cells comprises three types of filaments. The intermediate filaments, which are rigid and permanent, strengthen cells against mechanical stress; their composition depends on cell type. In mesenchymal cells, they are homopolymers of vimentin or desmin in the cytoplasm and of lamins in the inner surface of the nuclear membrane (Raats and Bloemendal, 1992). The microtubules are hollow tubes that play a crucial role in cell organization and drive intracellular transport via motor proteins; they consist mainly of tubulin. Finally, the microfilaments are thin and flexible, essential for intracellular movements, and consisting of actin and myosin. Actin exists as six different isoforms: two cytoplasmic or nonmuscle actins ( $\beta$ and $\gamma$ ), and four muscle actins (two striated muscle actins: $\alpha$-skeletal and $\alpha$-cardiac; and two SM actins: $\alpha$ and $\gamma$ ) (Vandekerckhove and Weber, 1978; Buckingham et al, 1984). The actin filament is a two-stranded helix of actin monomers and can associate with a myriad of actin binding proteins (capping, severing, cross-linking, bundling, nucleating, sequestering, or motor proteins) that enable the filament to perform a variety of functions. Myosins are motor proteins that hydrolyze ATP, providing the energy for their movement along actin filaments. A large variety of myosin isoforms is present in muscle (striated or smooth) and nonmuscle cells. Conventional or class II myosins are hexamers of two heavy chains and two pairs of light chains (Loukianov et al, 1997; Schiaffino and Reggiani, 1996). Numerous recent studies have illuminated our understanding of dynamics of actin cytoskeleton. Assembly and disassembly of actin filament bundles result from the association of various actin binding proteins and are regulated by small GTPases related to the Ras superfamily. Rearrangement of actin cytoskeleton, particularly at the surface membrane, mediates different cellular processes. Rho GTPases for instance, in response to extracellular signals, regulate the interaction between stress fibers, contractile actin-myosin filaments and focal adhesion complexes (Hall, 1998; Machesky and Hall, 1996; Molitoris, 1997). Markers of actin cytoskeleton are thus good tools to evaluate phenotypic modifications in response to physiologic or pathologic situations. Fully differentiated myofibroblasts express $\alpha$-SM actin. However, as underlined recently by Tomasek et al (2002), in some situations fibroblastic cells show morphologic characteristics of myofibroblasts, including microfilament bundles of cytoplasmic actins, but do not express $\alpha$-SM actin. It has been proposed to term these cells "proto-myofibroblasts" (Tomasek et al, 2002). Usually, cultured fibroblastic cells in the presence of fetal calf serum exhibit a mixture of protomyofibroblastic and more differentiated myofibroblastic phenotypes; the presence of $\alpha$-SM actin is directly related to the contractile activity of myofibroblasts. Indeed, it has been recently demonstrated both in vitro and in vivo a direct correlation between the level of $\alpha$-SM actin expression and myofibroblast contraction (Hinz et al, 2001a, 2001b). This point, and the role of mechanical factors in proto-myofibroblastic and myofibroblastic differentiation, will be discussed extensively below (see "Force Generation by the Myofibroblast: Role and Factors Involved" section). Protomyofibroblasts and myofibroblasts can also express other SM cytoskeletal proteins, including desmin, caldesmon, and SM-myosin heavy chains (for review, see Desmoulière and Gabbiani, 1996); however, while particularly useful in vivo to characterize the SM differentiation of the fibroblastic cells in different pathologic situations, the roles of these proteins are not fully understood. In contrast, differentiated myofibroblasts do not express smoothelin, a recently described late differentiation marker of both vascular and parenchymal SM cells (Christen et al, 2001; Van der Loop et al, 1997). The expression of smoothelin is at present the most reliable criterion to distinguish between the differentiated myofibroblast, as defined here, and the mature SM cell (Van der Loop et al, 1996).

\section{Myofibroblasts during Normal Healing in the Skin}

Normal wound healing includes a number of overlapping phases. After injury, there is an early inflammatory step characterized by hemorrhage and clotting. During this phase, platelet degranulation occurs, releasing a cocktail of growth factors into the local environment that helps to attract inflammatory cells, particularly monocytes and granulocytes, to the site of damage. These cells in turn release numerous factors that stimulate the repair process. At this time, the wound has a provisional extracellular matrix consisting largely of fibrin. This provisional matrix serves to seal the wound temporarily and allows the invasion of cells that carry out the repair process by fibrogenesis and angiogenesis (Yamada and Clark, 1996). It also provides a substrate on which epithelial cells migrate to re-epithelialize the wound. In the next phase, allowing the development of the granulation tissue, fibroblasts invade the wound and commence replacing the provisional matrix with a more mature wound matrix containing collagen, fibronectin, and other matrix molecules. In this phase, angiogenesis is also occurring, predominantly from the damaged pre-existing vessels; there is also limited evidence of circulating precursors of endothelial cells that could potentially be involved (Kalka et al, 2000). The fibroblasts present during the early granulation tissue phase resemble immature fibroblasts with a highly synthetic appearance, containing abundant cisternae of rough endoplasmic reticulum. However, as the granulation tissue phase proceeds, fibroblasts start showing a new phenotype with prominent microfilament bundles and dense bodies visible by electron microscopy (Gabbiani et al, 1971). These typical myofibroblasts have been shown to be $\alpha$-SM actin-positive by immuno- 
staining and the microfilament bundles themselves are $\alpha$-SM actin-positive by immuno-electron microscopy (Darby et al, 1990). In addition to $\alpha$-SM actin, granulation tissue myofibroblasts may express other markers of SM cell differentiation, such as desmin and SM myosin heavy chains, but this is generally observed only in hypertrophic scarring. Keloid scars, though they show the presence of fibroblasts with stress fibers, generally exhibit few SM cell markers, being myosin heavy chain and desmin negative (Ehrlich et al, 1994).

During the granulation phase of healing, myofibroblasts are responsible for facilitating wound closure both by tractional forces and by contraction. The focal adhesions that the myofibroblasts have with the extracellular matrix and the fibronexi that these cells exhibit allow them to pull both on the extracellular matrix and transmit force to neighboring cells (Singer et al, 1984; Eyden, 1993). Gap junctions between cells also allow communication between adjacent myofibroblasts. It has long been known that myofibroblastcontaining granulation tissue can contract ex vivo in response to vasoactive hormones or peptides (Higton and James, 1964; Majno et al, 1971); recent in vitro data confirm their ability to contract (eg, on flexible substrates) and the dependence of this contractile ability on the presence of $\alpha$-SM actin (see "Force Generation by the Myofibroblast: Role and Factors Involved" section below) (Hinz et al, 2001a).

The growth factors involved in stimulating fibroblast proliferation and differentiation into myofibroblasts and extracellular matrix synthesis are discussed in detail below in section "Modulation of Fibroblast Phenotype." In the granulation tissue, there are many cells that can release growth factors such as TGF- $\beta$ and platelet-derived growth factor, starting with platelets that degranulate early in healing and the inflammatory cells such as granulocytes and monocytes attracted into the wound. Once the healing process has started, wound cells such as fibroblasts also express growth factors that may act in an autocrine and paracrine manner. An important source of growth factors involved in the repair process is the wounded epithelium, which has been shown to express high levels of several factors, particularly at the wound margins where hyperproliferative keratinocytes are present. Wound cells, including dermal fibroblasts and keratinocytes, show high expression levels of TGF- $\beta$, epidermal growth factor, keratinocyte growth factor, and vascular endothelial growth factor to name a few (Bascom et al, 1989; Brown et al, 1992; Werner et al, 1992). These factors can stimulate myofibroblast differentiation and extracellular matrix synthesis (eg, TGF- $\beta$ ), proliferation of granulation tissue cells, and the elongation of capillaries from the damaged ends of pre-existing vessels. The importance of communication in a paracrine manner between the epidermis and the dermis is shown by studies on hypertrophic scars where a persistence of activated keratinocytes in the epidermis implicates abnormal epidermal-mesenchymal interactions, and suggests that cellular mechanisms in the pathogenesis of hypertrophic scarring are very complex (Machesney et al, 1998). Furthermore, keratinocyte growth factor, or fibroblast growth factor 7, a 18.9-kD member of the fibroblast growth factor family, is synthesized by skin fibroblasts (Werner et al, 1992). However, its mitogenic activity is on epidermal keratinocytes, where it is the most potent growth factor identified thus far. This illustrates the important dialogue between epidermis and dermis, which occurs through the basement membrane. Recently, it has been shown that activin, a TGF- $\beta$ superfamily member, plays an important role in both keratinocyte differentiation and granulation tissue formation (Beer et al, 2000). In some organs (eg, the kidney), an epithelio-mesenchymal transdifferentiation has been described (see "Origin of Renal Myofibroblasts" section below) (Okada et al, 1996); however, in the skin this process has not been implicated.

Lastly, in the resolution phase of healing, there is considerable loss of various cell types, including myofibroblasts, by apoptosis (Darby et al, 1990; Desmoulière et al, 1995). The fibroblasts that remain in granulation tissue after the epithelial defect is closed have reverted to a more quiescent, noncontractile phenotype lacking the microfilament bundles that were present during the contractile phase of healing. It is also conceivable that the residual fibroblasts represent a population of cells that failed to acquire a myofibroblast phenotype during healing and thus survive, while the myofibroblastic cells that appeared during healing represent terminally differentiated cells that undergo apoptosis during the resolution phase. The signal for this cell death is unknown but may be related to reductions in the concentrations of local trophic factors as re-epithelialization and depletion of inflammatory cells occurs later in healing. Also, the remodeling of the extracellular matrix by metalloproteinases may also play a role by interfering with myofibroblast adhesion to the extracellular matrix as has been suggested by studies on regression of granulation tissue under a vascularized skin flap and by studies on resolution of liver fibrosis (Darby et al, 2002; Iredale et al, 1998). Early in wound repair, the balance between matrix metalloproteinases such as collagenases and gelatinases and their endogenous inhibitors, tissue inhibitor of metalloproteinases (TIMPs), favors extracellular matrix production. Later in wound healing as remodeling occurs, it is possible that this balance changes and favors matrix degradation and remodeling. As mentioned above, this could potentially result in increased apoptosis. Data from chronic wound studies show that there is generally an imbalance between metalloproteinases, particularly gelatinases, elastase, and TIMPs in chronic wounds (Wysocki et al, 1993). Whether this results in increased apoptosis in chronic wounds has not yet been conclusively determined. Changes in the physical stress caused by stretch of the granulation tissue may also contribute to the loss of cells via an apoptotic mechanism as has been suggested by in vitro studies of fibroblasts in collagen lattices (Grinnell et al, 1999). It has been speculated that excessive apoptosis may be 
involved in delayed or impaired healing such as that seen in aging or diabetes mellitus. Conversely, inappropriate delay of apoptosis, and thus increased survival of myofibroblasts activated during the healing process, may be a factor that leads to excessive scarring such as that seen in hypertrophic scars or keloids. This latter proposition, however, lacks conclusive evidence to date. Recent papers have shown data supporting the possibility that there is increased survival of fibroblasts from keloid scars in response to signals that would normally induce apoptosis (Chodon et al, 2000; Ishihara et al, 2000), while other studies suggest a possible imbalance between proliferation and apoptosis in keloids and hypertrophic scars but without clear evidence of decreased levels of apoptosis (Akasawa et al, 2001; Luo et al, 2001). The expression of genes that are protective against apoptosis, such as Bcl-2, has been shown to be increased in keloids and hypertrophic scars, suggesting a mechanism through which an imbalance between proliferation and apoptosis may be achieved (Teofoli et al, 1999). In hypertrophic scars, $\alpha$-SM actin-positive myofibroblasts are commonly present in nodules of cells, while fibroblasts in keloids are generally $\alpha$-SM actin-negative. Interestingly, when the fibroblasts from these types of scar are cultured, they give rise to similar numbers of myofibroblasts, suggesting that the microenvironment present within the scar is important for regulating the phenotype (Ehrlich et al, 1994).

In fetal wounds, healing can occur without scarring or contracture. This ability is lost in late gestation. Fetal skin fibroblasts are able to contract collagen lattices but show reduced staining for $\alpha$-SM actin. In vivo, early fetal wounds also show markedly fewer $\alpha$-SM actin-staining fibroblasts than in late fetal wounds or in adult wounds where $\alpha$-SM actin-positive myofibroblasts are abundant (Estes et al, 1994). Larger size of fetal wounds and a longer duration of $\alpha$-SM actin-positive myofibroblasts have been reported to correlate with adult-like scarring rather than scarless fetal healing (Cass et al, 1997). Additionally, fetal fibroblasts show less contractility in vitro than those derived from adult skin and do not respond to TGF- $\beta$ in the same manner, showing no increase in $\alpha$-SM actin expression (Moulin et al, 2001).

Recently, a strain of mouse, the Murphy Roths Lymphoma/Leukemia (MRL), has been described that displays a remarkable capacity for wound closure, providing an example of a phenomenon previously considered to be a form of regeneration (Clark et al, 1998). Compared with C57BL/6 mice, as early as Day 2 after full-thickness through-and-through ear punches, rate of reepithelialization, annular swelling, rapid connective tissue proliferation, angiogenesis, and chondrogenesis are increased in MRL mice. Interestingly, after heart injury, MRL mice also heal with little scarring and show nearly full myocardial replacement after injury (Leferovich and Heber-Katz, 2002). The accumulation of extracellular matrix was far less in the MRL mouse around the wound site than in the control, and the matrix metalloproteinase response far greater in the MRL than in the control (Leferovich and
Heber-Katz, 2002). In this interesting model, further studies are necessary to know the behavior of granulation tissue myofibroblasts and to understand how regeneration could be obtained by acting on the extracellular matrix deposition/degradation balance.

\section{Origin of Wound Myofibroblasts}

The origin of myofibroblasts in wound tissue has been assumed to be from local recruitment of fibroblasts from the surrounding dermis (Grillo, 1963; MacDonald, 1959; Ross et al, 1970). This is supported by the presence of many fibroblasts showing proliferation marker-positive nuclei (eg, bromodeoxyuridine) at the periphery of the wound and with matrix metalloproteinase-positive fibroblasts suggestive of cell migration, again at the wound margins (Fig. 1) (Darby et al, 1997). However, some evidence also exists for circulating precursor cells that may migrate into the wound and contribute to the fibroblastic population in the granulation tissue (Abe et al, 2001). Similar evidence also exists for circulating endothelial precursor cells (Kalka et al, 2000). The importance of these circulating cells remains to be shown and it seems likely that the major source of fibroblasts in granulation tissue is local recruitment by chemotaxis and subsequent migration from the surrounding dermis. There is also a possible source of myofibroblasts derived from pericytes or SM cells around vessels in the granulation tissue. In some studies, morphologic observations have suggested a possible origin of myofibroblasts from vascular SM cells. Overall, however, it seems likely that the majority derive from local pre-existing fibroblasts in the dermis, which gradually acquire the myofibroblast phenotype, as is suggested by the gradual appearance of microfilaments at the electron microscope level and $\alpha$-SM actin positivity at the light microscope level.

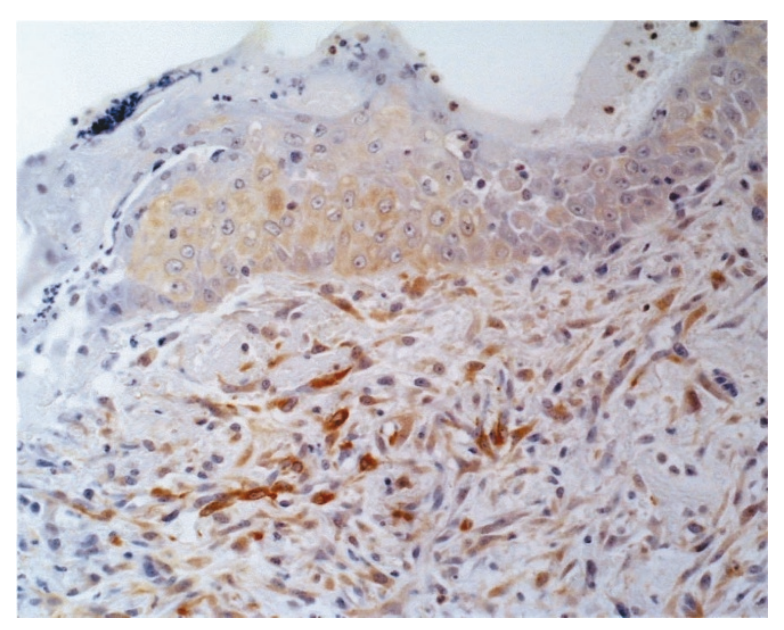

Figure 1.

Matrix metalloproteinase-1 expression in full-thickness skin wound made in rat. The strong immunostaining for matrix metalloproteinase-1 in wound myofibroblasts just below the migrating keratinocytes suggests that the myofibroblasts participating in granulation tissue formation are migrating from the border of the wound. $\times 250$. 


\section{Modulation of Fibroblast Phenotype}

Cytokines. The application of granulocytemacrophage colony-stimulating factor (GM-CSF) to the rat subcutaneous tissue induces the formation of an important granulation tissue rich in $\alpha$-SM actinpositive myofibroblasts (Rubbia-Brandt et al, 1991). In vitro experiments have shown that GM-CSF does not directly stimulate $\alpha$-SM actin expression when added to the culture medium of rat or human fibroblasts. Indeed, after GM-CSF local treatment, the appearance of $\alpha$-SM actin-rich myofibroblasts (RubbiaBrandt et al, 1991) is preceded by a characteristic cluster-like accumulation of macrophages (Vyalov et al, 1993), suggesting that such macrophages are important in the stimulation of $\alpha$-SM actin synthesis by myofibroblasts. During the early steps of pulmonary fibrosis development after intra-alveolar instillation of bleomycin, GM-CSF is expressed by inflammatory cells (Andreutti et al, 1998). Moreover, GM-CSF induces the expression of TGF- $\beta 1$ mRNA by alveolar macrophages (Andreutti et al, 1998). These data support the possibility that GM-CSF participates in the initial steps of the chain of events leading to granulation tissue formation in normal healing and to fibrosis in pathologic situations, perhaps through a stimulation of TGF- $\beta 1$ production. Indeed, among factors secreted by activated macrophages and capable of modulating the expression of $\alpha$-SM actin, TGF- $\beta 1$ is probably the most efficient (Desmoulière et al, 1993). We and others have shown that TGF- $\beta 1$ stimulates the expression of $\alpha$-SM actin in granulation tissue myofibroblasts (Desmoulière et al, 1993; Ronnov-Jessen and Petersen, 1993). The action of TGF- $\beta 1$ on $\alpha$-SM actin expression confirms and extends the notion that TGF- $\beta 1$ plays an important role in both myofibroblast differentiation and extracellular matrix deposition. Among the molecules regulated by TGF- $\beta 1$, connective tissue growth factor (CTGF) has received significant attention. CTGF belongs to a family of earlyresponse genes (Bork, 1993), comprising both positive and negative regulators of cell growth. In vitro studies have demonstrated that CTGF is a downstream mediator of several effects of TGF- $\beta 1$ and notably extracellular matrix synthesis and fibroblast proliferation (Duncan et al, 1999; Frazier et al, 1996; Kothapalli et al, 1997). Increasing evidence from in vivo and in vitro models of tissue remodeling and fibrosis suggest that CTGF may represent a downstream effector molecule of the profibrotic activities of TGF- $\beta 1$ in the maintenance and repair of connective tissues and in disease evolution. However, it has been shown that the addition of recombinant CTGF to rabbit corneal fibroblast cultures does not significantly increase $\alpha$-SM actin mRNA or protein nor does it appear to affect assembly of $\alpha$-SM actin stress fibers (Folger et al, 2001); thus, CTGF is not the TGF- $\beta$ mediator of the corneal fibroblast to myofibroblast transition. The authors suggest that CTGF may play a supporting role in myofibroblast differentiation.

In contrast, different cytokines can inhibit the myofibroblastic differentiation. In cultured fibroblasts, $\gamma$-interferon ( $\gamma \mathrm{IFN}$ ), a cytokine produced by T-helper lymphocytes, decreases $\alpha$-SM actin protein and mRNA expression as well as cell proliferation (Desmoulière et al, 1992a). Preliminary results (Pittet et al, 1994) have shown that $\gamma$ IFN treatment decreases the symptoms and the size of hypertrophic scars and Dupuytren's nodules. In hypertrophic scars, immunofluorescence examination showed that $\alpha$-SM actin expression was decreased in myofibroblasts of treated lesions.

Extracellular Matrix Components. It is well accepted that the extracellular matrix represents a structural support for cellular constituents, but the matrix plays also a central role as a source of signals influencing growth and differentiation of different cell types, including fibroblasts (For review, see Juliano and Haskill, 1993). Among extracellular matrix components, different types of collagen, glycoproteins, and proteoglycans could be involved in myofibroblastic differentiation. In proliferating fibroblasts cultured in the presence of fetal calf serum and in vivo, heparin increases the expression of both $\alpha$-SM actin protein and mRNA (Desmoulière et al, 1992b). Fibronectin is a prominent matrix component that promotes cell migration during development and has important functions in several steps of wound healing. Molecular cloning has demonstrated that fibronectin exists in multiple forms that arise from a single mRNA transcript that can be alternatively spliced in three regions: EIIIA (ED-A), EIIIB, and V. During cutaneous wound healing, both macrophages and fibroblasts express ED-A- and EllIB-fibronectin mRNA (Brown et al, 1993). Recently, Serini et al (1998) have shown that the fibronectin isoform ED-A is necessary for the induction of the myofibroblastic phenotype by TGF- $\beta 1$.

\section{Force Generation by the Myofibroblast: Role and Factors Involved}

During the past years, it has become more and more evident that mechanical stress is crucial for the fibroblast-myofibroblast modulation (For review, see Tomasek et al, 2002). This is particularly true for the initial phases of proto-myofibroblast development both in vitro and in vivo (Hinz et al, 2001a; 2001b). Mechanical stress is also important during the evolution of proto-myofibroblast to differentiated myofibroblast, but in this situation the concurrent activity of TGF- $\beta 1$ (Desmoulière et al, 1993) and ED-A fibronectin (Serini et al, 1998) are also required.

Another important point recently clarified is the direct participation of $\alpha$-SM actin in force generation by the myofibroblast. Several laboratories have shown that this actin isoform is responsible for the incremental force generation that is observed in differentiated myofibroblasts when compared with protomyofibroblasts (Arora and McCulloch, 1994; Hinz et al, 2001a, 2001b). The mechanisms of this activity are not presently clear. It is tempting to speculate that $\alpha$-SM actin interaction with nonmuscle and/or SM myosin results in the production of a stronger force compared with $\beta$ - and $\gamma$-cytoplasmic actin isoforms. 
It should be stressed that the mechanisms of force generation by the myofibroblast are different from the mechanisms of force generation by the SM cell. The myofibroblast exerts its contractile activity by producing a persistent isometric contraction that is reflected by extracellular matrix retraction. This retraction is then stabilized by new deposition of matrix components such as collagen type III and type I, and this results in overall tissue shortening. All these observations suggest that the mechanisms of force generation are essentially different in myofibroblasts compared with SM cells. Indeed it appears that the myofibroblast contraction does not involve directly $\mathrm{Ca}^{++}$-regulated mechanisms but rather Rho-Kinase pathway through a modulated activity of myosin phosphates (for discussion of this point, see Tomasek et al, 2002). Recently it has been shown that thrombin-induced contraction of a collagen gel populated by cultured human lung myofibroblasts depends on the overexpression of both constitutively active PCKepsilon and constitutively active RhoA that can form a ternary complex with $\alpha$-SM actin (Bogatkevich et al, 2003). In this respect it should be noted that the inhibition of the myofibroblast contractile activity by the intracellular administration of the $\mathrm{N}$-terminal peptide of $\alpha$-SM actin has been shown to decrease collagen synthesis probably through an indirect mechanism involving tension decrease (Hinz et al, 2002).

\section{Myofibroblastic Cells in Liver Pathology}

Human Pathologies. When liver injuries and associated acute inflammation response result in moderate cell necrosis and extracellular matrix damage, tissue repair takes place, replacing dead cells by normal tissue, with regeneration of specialized cells by proliferation of the surviving ones, formation of a granulation tissue, and tissue remodeling (see "Myofibroblasts during Normal Healing in the Skin" section above). However, many liver diseases are chronic, and liver fibrosis is the main complication resulting of these chronic injuries. Chronic injury leading to fibrosis in liver occurs in response to a variety of injury, including alcohol abuse, viral hepatitis (especially hepatitis $B$ and $\mathrm{C}$ ), drugs, metabolic diseases due to overload of iron or copper, autoimmune attack of hepatocytes or bile duct epithelium, or congenital abnormalities (For review, see Friedman, 1998).

Liver fibrosis is defined as the accumulation of an excess of extracellular matrix components in the organ. Its endpoint is cirrhosis, which is responsible for significant morbidity and mortality. Cirrhosis is defined as an advanced stage of fibrosis, characterized by the formation of regenerative nodules of liver parenchyma, which are separated by and encapsulated in fibrotic septa. These septa are populated by (myo)fibroblastic cells that lie embedded in large amounts of extracellular matrix. Usually, injury can be present for months to years before significant lesions accumulate; however, in congenital liver diseases, such as biliary atresia, the time course may be accelerated. It is accepted that liver fibrosis is reversible, whereas cir- rhosis is generally irreversible (Bioulac-Sage et al, 2000). Prevention of fibrosis to cirrhosis progression is thus a major clinical goal that is only partly fulfilled by the current treatments of the causative diseases. The poor prognosis of cirrhosis is in great part consecutive to the frequent occurrence of hepatocellular carcinoma. Hepatocellular carcinoma can also develop much more rarely on a normal or slightly fibrous liver.

Cells Involved, Experimental Models, and Mechanisms. Extracellular matrix deposition is consecutive to the activity of fibrogenic cells known as liver myofibroblasts. Myofibroblasts are almost absent from normal liver; they derive from the activation of precursor cells, the best studied being hepatic stellate cells. Hepatic stellate cells are characterized by their perisinusoidal localization and their long processes extending along and around sinusoids and between hepatocytes. Cytoplasmic lipid droplets are present in a majority $(75 \%)$ of hepatic stellate cells in normal liver (Bioulac-Sage et al, 1988; Sztark, 1986) and contain vitamin $A$; hepatic stellate cells harbor the largest quantity of vitamin $A$ in the body.

We and others have put forward the concept of heterogeneity of liver fibrogenic cells by showing that portal fibroblasts present in portal tracts also play a major role in liver fibrogenesis. Moreover, second layer cells present around centrolobular veins described by Bhunchet and Wake (1992), fibroblasts present in the Glisson capsule surrounding the liver, and vascular SM cells of portal vessel wall could also be involved in fibrogenesis, probably by modulation to myofibroblastic cells.

Different experimental models of liver injury have been described. These models characterize the fibroblastic cells involved in the development of the lesion. After carbon tetrachloride $\left(\mathrm{CCl}_{4}\right)$ treatment, necrosis occurs around centrolobular veins; in this case, hepatic stellate cells, but also probably second layer cells, are activated and involved in repair processes (Fig. 2, A and B). Periductular fibroblasts are involved in the portal fibrosis induced by common bile duct ligation (Kinnman et al, 2003; Tuchweber et al, 1996). This model is characterized by a moderate inflammation, and the main factors inducing portal lesion are increased biliary pressure (Slott et al, 1990) and probably modifications in bile composition. Cytokines such as platelet-derived growth factor (Kinnman et al, 2003) and CTGF (Sedlaczek et al, 2001) are also involved. Proliferation of bile duct structures induced by bile duct ligation is accompanied by a proliferation of portal fibroblasts forming onion-like structures around bile ducts; these portal fibroblasts acquire a myofibroblastic phenotype and are involved in the early deposition of extracellular matrix in the portal zones (Desmoulière et al, 1997b) (Fig. 2, C and D). Secondary biliary cirrhosis with bile duct proliferation and portal fibrosis can be induced by bile duct occlusion after injection in a retrograde manner with the sclerosant sodium amidotriazoate (Ethibloc, Ethicon, Norderstedt, Germany) (Boigk et al, 1997; Cho et al, 2000). In our hands, this model induces an early inflammation due to biliary epithelial cell necrosis; thus, the mech- 


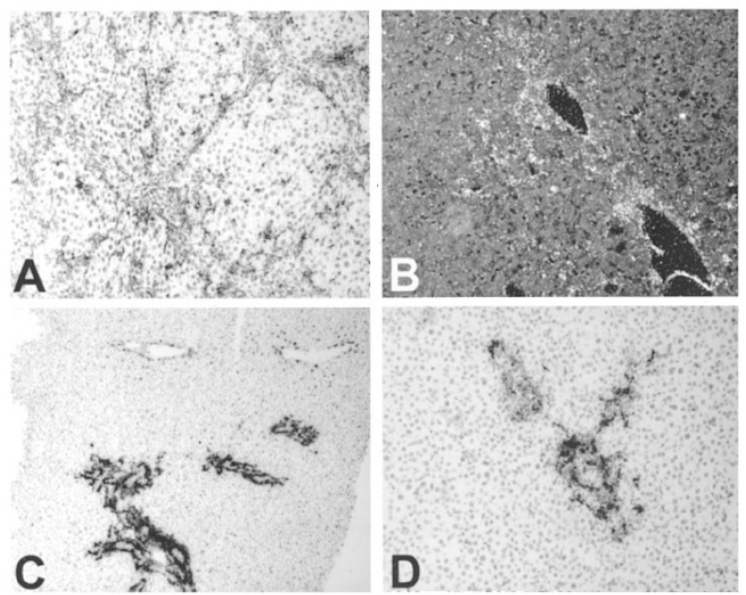

Figure 2.

Procollagen I mRNA expression in carbon tetrachloride $\left(\mathrm{CCl}_{4}\right)$-treated $(\mathrm{A}, \mathrm{B})$ and bile duct ligated (C, D) rats. $\mathrm{CCl}_{4}$-treated liver sections show high expression of procollagen I mRNA in areas of fibrosis and in hepatic stellate cells (A); procollagen I mRNA expression is radiating from the central vein and is largely confined to hepatic stellate cells (B, dark field microscopy). In bile duct ligated liver section, high levels of procollagen I mRNA expression are seen around the portal spaces close to bile ducts (C, D), but some labeling of hepatic stellate cells is also observed (C). A $\times 130$; B and D, $\times 65 ; C, \times 30$.

anisms inducing portal fibrosis are different compared with the classical bile duct ligation. Vascular SM cells residing in the wall of portal vein branches and portal arteries are implicated in the portal/periportal fibrosis characteristic of chronic schistosomiasis (Andrade et al, 1999).

Fibrosis can also be induced by ip injections of pig serum to rats (Bhunchet and Wake, 1992; Rubin et al, 1968). In these pig serum-sensitized animals, accumulation of connective tissue is present in centrolobular and periportal zones, and no necrotic hepatocytes or acute inflammatory reactions are observed. Prominent fibrotic septa are observed extending in a radial pattern from central veins and portal zones, resulting in the formation of pseudolobules. In this model, the mechanism that leads to the hepatic fibrosis is unknown.

Myofibroblasts are a major component of the stroma reaction that develops around hepatocellular carcinoma. These myofibroblasts are involved in the synthesis of stromal extracellular matrix components (Faouzi et al, 1999; Le Bail et al, 1999), of extracellular matrix-degrading proteinases such as urokinase (Dubuisson et al, 2000; Monvoisin et al, 1999) or matrix metalloproteinase-3 (Monvoisin et al, 2002), and of proinvasive factors including hepatocyte growth factor (Neaud et al, 1997, 2000). Different models have been proposed to study hepatocellular carcinoma development. However, in most of them, stroma reaction is practically absent. Recently, a model associating diethylnitrosamine exposure and $\mathrm{N}$-nitrosomorpholine treatment (Futakuchi et al, 1999) exhibited interesting histologic features of hepatocellular carcinoma surrounded by a stroma reaction resembling that observed in humans (Taras D, Desmoulière A, Rosenbaum J, unpublished data).
All of these findings suggest that it is necessary to re-evaluate the role of the hepatic stellate cells in the development of liver fibrosis. The pericyte-like characteristics of hepatic stellate cells, including their close relationship with endothelial cells and their SM markers expression have been discussed extensively in previous publications (Blomhoff and Wake, 1991; Pinzani, 1995). Hepatic stellate cells are probably "resting pericytes," which can be rapidly activated (eg, as a consequence of blood pressure modifications), acquiring contractile properties, which in turn can regulate the local blood pressure. We observed the early activation of hepatic stellate cells during the transplantation procedure as evidenced by an acute and transient expression of $\alpha$-SM actin (RubbiaBrandt et al, 1997). Moreover, ex vivo liver perfusion induces (a) an early activation of hepatic stellate cells which acquire the expression of $\alpha$-SM actin, and (b) significant changes in the perisinusoidal extracellular matrix (Costa et al, 2001). These results are compatible with the view that hepatic stellate cells function as liver specific pericytes participating in the regulation of sinusoidal blood pressure. Furthermore, it has been mentioned that pure populations of hepatic stellate cells do not proliferate (Knittel et al, 1999b; personal observations). It has been suggested that in many studies using several fold-passaged hepatic stellate cells, liver fibroblastic cells different from typical hepatic stellate cells (eg, portal fibroblasts) were analyzed; moreover, the existence of distinct subpopulations of hepatic stellate cells has been shown (Ballardini et al, 1994). Thus, a clear classification of the different liver fibroblastic cells studied in vitro should be made and extrapolations to pathologic situations from in vitro studies must be subjected to critical evaluation. Figure 3 attempts to describe the behavior of the different fibroblastic cells present in the liver.

Markers of Liver Myofibroblasts. Numerous markers have been used to identify the fibroblastic cells involved in liver fibrosis (Cassiman et al, 2002; Knittel et al, 1999a, 1999b). In addition to classical mesenchymal markers such as desmin for rat hepatic stellate cells, $\alpha$-SM actin for activated hepatic stellate cell, and vimentin for human and rat hepatic stellate cell, liver

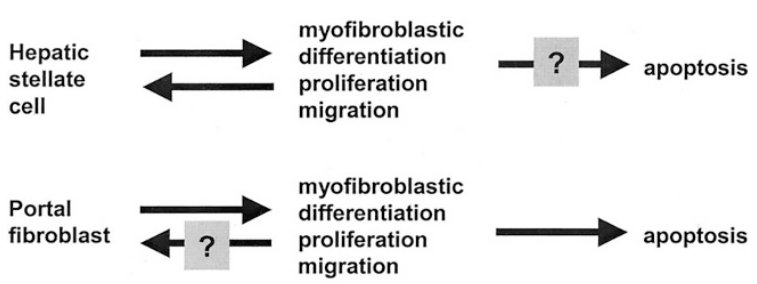

Figure 3

Different liver fibroblastic cell populations involved in fibrogenesis and their suggested behavior during remodeling of fibrotic tissue. Similar to pericytes, hepatic stellate cells can modulate their myofibroblastic differentiation, and particularly their $\alpha$-SM actin expression in response to modification of sinusoidal blood pressure; in these cells, the myofibroblastic differentiation appears reversible. The myofibroblastic differentiation of portal fibroblasts resembles that of dermal fibroblasts and seems to be a terminal differentiation requiring apoptosis for cell disappearance. 
(myo)fibroblastic cells express neural/neuroendocrine features such as silver staining, neural-cell adhesion, glial fibrillary acidic protein, nestin, synaptophysin, neurotrophins, and neurotrophin receptors (for review, see Cassiman and Roskams, 2002). Human and rat hepatic stellate cells also express alpha B-crystallin (Cassiman et al, 2001).

During wound healing of a full-thickness rat skin wound, cellular retinol-binding protein-1 (CRBP-1) is transiently expressed by a significant proportion of fibroblastic cells including myofibroblasts $(\mathrm{Xu}$ et al, 1997), suggesting that it plays a role in the evolution of the granulation tissue. CRBP-1 is highly expressed in the liver, particularly in hepatic stellate cells. CRBP-1 is involved in vitamin A metabolism as it mediates both retinol esterification to retinyl esters and retinol oxidation to retinal and retinoic acid. Recently, we have observed that in normal liver portal fibroblasts did not express CRBP-1 contrary to hepatic stellate cells (Uchio et al, 2002). After $\mathrm{CCl}_{4}$ injury, CRBP-1 expression was maintained in myofibroblastic $\alpha$-SM actinpositive hepatic stellate cells. After bile duct ligation, portal fibroblasts (proliferating around ductular structures) acquired expression of both CRBP- 1 and $\alpha$-SM actin. During hepatic stellate cell activation in culture, CRBP-1 expression gradually increased until Day 5 when $\alpha$-SM actin expression was obvious. Cultured portal fibroblasts developed both CRBP- 1 and $\alpha-\mathrm{SM}$ actin expression. In both cell populations, TGF- $\beta 1$ treatment increased CRBP-1 expression. Thus, in normal liver, CRBP-1 expression is different in different fibroblastic cells, a finding that adds to the concept of heterogeneity of liver fibrogenic cells. Furthermore, during myofibroblastic differentiation, hepatic stellate cells lose their stores of retinol and maintain a high level of CRBP-1 expression, while portal fibroblasts acquire CRBP1 expression. Together, these data suggest a correlation between CRBP-1 expression and myofibroblastic differentiation. Furthermore, recent observations demonstrate that CRBP-1 is a good marker to identify quiescent hepatic stellate cells present in normal human liver (Fig. 4A). In pathologic conditions, immunostaining of both CRBP-1 and $\alpha$-SM actin helps to identify a wide range of hepatic stellate cell phenotypes and allows the identification of different (myo)fibroblast-like subpopulations (Fig. 4B).

It has also been shown recently that portal fibroblasts express ecto-nucleoside triphosphate diphosphohydrolases, which hydrolyze extracellular nucleotides and are therefore potential regulators of nucleotide-mediated signaling (Dranoff et al, 2002). According to the authors, this distribution may represent a previously unrecognized mechanism for the regulation of nucleotide signaling in bile duct structures.

In Vivo and In Vitro Studies of Fibrosis Resolution. We have shown that apoptosis mediates the decrease in cellularity during the transition between skin granulation tissue and scarring (Desmoulière et al, 1995, 1997a). This observation has now been extended to other organs. Thus, in the liver, myofibroblasts derived from hepatic stellate cells disappear by apoptosis
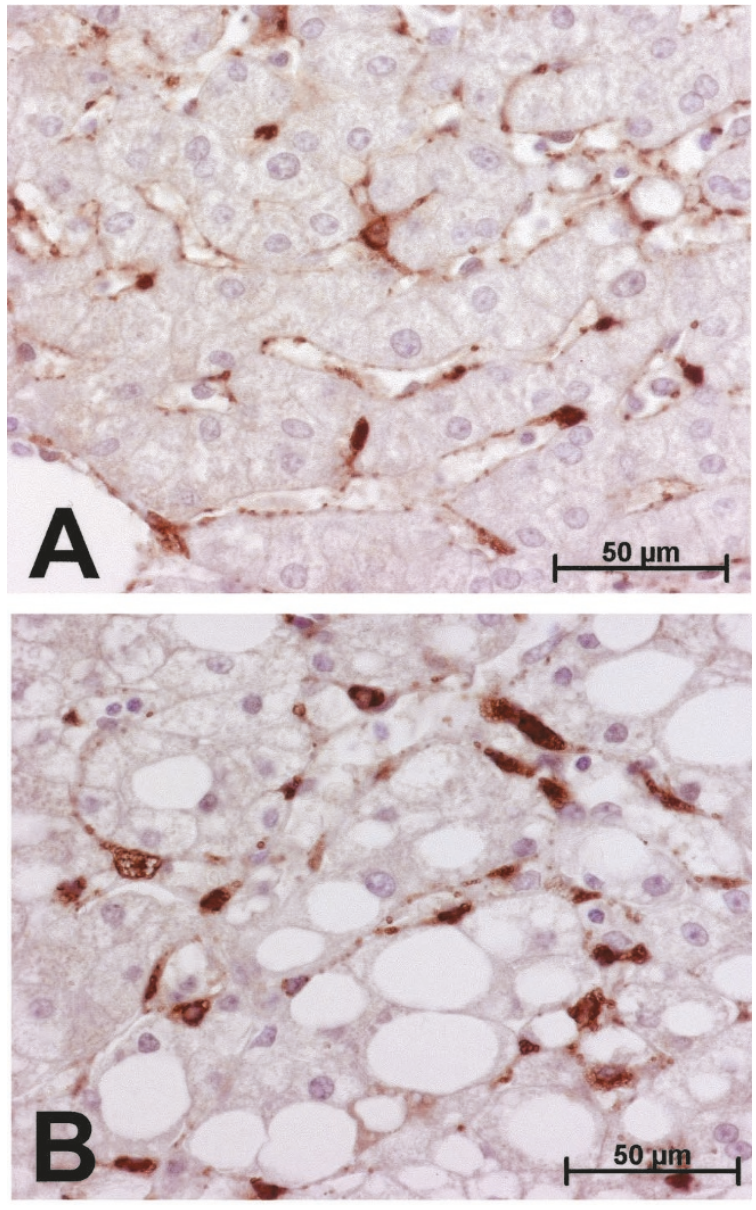

Figure 4.

Cellular retinol-binding protein-1 (CRBP-1) expression in human normal liver (A) and in steatosis (B). In normal liver (A), immunostaining with the antibody against CRBP-1 detects a very low expression in hepatocytes. In contrast, it allows perfect highlighting of hepatic stellate cells clearly located beneath the endothelial cells; delicate cytoplasmic processes along sinusoids and sometimes between hepatocytes are very finely underlined by the CRBP- 1 immunostaining. In steatosis (B), the hepatic stellate cell bodies show numerous CRBP-1-negative lipid droplets inside their cytoplasm; delicate cytoplasmic processes positive for CRBP-1 are visible between steatotic enlarged hepatocytes and along sinusoids.

during the spontaneous resolution of rat liver fibrosis induced by $\mathrm{CCl}_{4}$ treatment (Iredale et al, 1998). During liver fibrosis, the activated hepatic stellate cells are a major source of TIMP-1. During spontaneous recovery from liver fibrosis, there is a decrease of TIMP expression, an increase in collagenase activity, and increased apoptosis of hepatic stellate cells, highlighting a potential role for TIMP-1 in hepatic stellate cell survival. Murphy et al (2002) have demonstrated that TIMP-1 directly inhibits hepatic stellate cell apoptosis via matrix metalloproteinase inhibition.

Reversibility of experimental cholestatic liver fibrosis following obstacle removal has been observed a long time ago (Birns et al, 1962; Cameron and Prasad, 1960). More recently, Hammel et al (2001) have studied a group of patients with cholestatic liver fibrosis who underwent surgical decompression of an obstructed biliary system. By comparing liver-biopsy specimens obtained before and after surgery, they 
observed in some patients a significant regression of the liver fibrosis after decompression. However, the mechanisms involved in fibrosis resolution remain essentially unknown. Recently, we have studied the effect of bilioduodenal anastomosis and of simple biliary decompression by bile aspiration on the remodeling of the lesion in bile duct-ligated rats (Costa et al, 2003). After anastomosis, collagen deposition and $\alpha$-SM actin expression were back to control values after 7 days. These parameters remained practically unchanged 24 hours after biliary decompression. After anastomosis or decompression, apoptosis of both fibroblastic and bile ductular cells increased greatly and was accompanied by ultrastructural features of extracellular matrix degradation. Biliary decompression and anastomosis did not modify total concentration and composition of the biliary bile acid pool. These observations demonstrate that in the model of cholestatic fibrosis induced by common bile duct ligation, the withdrawal of intraductal pressure is a sufficient stimulus to induce apoptosis in bile duct epithelial and portal fibroblastic cells and to elicit extracellular matrix remodeling; they help elucidate the mechanisms involved in regression of cholestatic diseases and highlight the role of mechanical stimuli on cell growth, phenotype, and death.

Innervation. The deficiency of a correct innervation, such as in paraplegic or quadriplegic patients, leads to an impaired healing of injuries below the level of spinal cord lesion (Basson and Burney, 1982; Olivari et al, 1972). In diabetic neuropathy, the healing is also impaired (Johnson and Doll, 1984). The exact mechanism by which nerve cells stimulate healing is not clear; one hypothesis is that impaired nociception may cause repeated trauma; another hypothesis is that neuropeptides stimulate cells involved in healing. In burn wound healing, nerve regeneration takes place concomitantly with angiogenesis during granulation tissue development (Kishimoto, 1984).

Neuropeptides are synthesized in the neuronal body and released at the periphery by axons where they modulate local blood flow (Wallengren, 1997), inflammation (neurogenic inflammation) (Jancso et al, 1967), and immune functions (Maggi, 1997). Neuropeptides also stimulate proliferation of endothelial cells and fibroblasts in vitro (Nilsson et al, 1986; Ziche et al, 1990) and the production of cytokines by keratinocytes (Song et al, 2000). In rats, myofibroblastic differentiation precedes nerve regeneration probably because myofibroblasts produce neurotrophic factors (Liu et al, 1999), evincing mutual stimulation between fibroblasts-myofibroblasts and nerve cells. In the absence of noradrenergic signaling induced by chemical denervation with the toxic 6-hydroxydopamine (OHDA), which induces degeneration of dopaminergic terminal fibers, the healing of incisional cutaneous lesions is impaired (Kim et al, 1998).

Although it has been known for some time that hepatic stellate cells are in contact with nerve fibers (Bioulac-Sage et al, 1990; Ueno and Tanikawa, 1997), almost nothing is known regarding the function of this innervation. However, a few studies suggest that the adrenergic innervation and/or circulating catecholamines can influence the course of fibrogenesis. Isolated hepatic stellate cells respond to norepinephrine by increasing their secretion of prostaglandins (Athari et al, 1994). Prostaglandins decrease the proliferation of activated hepatic stellate cells (Mallat et al, 1996), and prostaglandin E1 treatment decreases liver fibrosis in the bile duct ligation model (Beno et al, 1993). One could thus conclude that catecholamines may have a protective effect against fibrogenesis. Furthermore, recent studies have shown that interruption of the parasympathetic innervation by vagotomy (LeSage et al, 1999) or interruption of the dopaminergic innervation by a single intraportal injection of OHDA (Glaser et al, 1999) markedly decrease bile duct epithelial cell proliferation in bile duct ligated rats, probably reducing portal fibroblast growth. The effects of noradrenergic antagonism on $\mathrm{CCl}_{4}$-induced liver fibrosis in rats have also been investigated (Dubuisson et al, 2002). Two weeks of $\mathrm{CCl}_{4}(375 \mu \mathrm{l} / \mathrm{kg}$ by gavage, three times a week) induced a $\sim 5$-fold increase in the area of fibrosis as compared with controls. Addition of OHDA decreased fibrosis by $60 \%$. After 6 weeks of $\mathrm{CCl}_{4}$, the area of fibrosis increased about 30 fold in $\mathrm{CCl}_{4}$-treated animals and was decreased by $36 \%$ with OHDA (Fig. 5, A and B). At 2 weeks, OHDA abrogated the $\mathrm{CCl}_{4}$-induced increase in mRNA level of TIMP-1, and it greatly reduced it at 6 weeks. Finally, when rats treated with $\mathrm{CCl}_{4}$ for 2 weeks also received prazosin, an antagonist of $\alpha 1$ adrenergic receptors, fibrosis was decreased by $83 \%$. Thus, destruction of noradrenergic fibers or antagonism of noradrenergic signaling through $\alpha 1$ receptors inhibited the development of liver fibrosis. As adrenoreceptor antagonists have a very good safety profile, they appear as attractive drugs to reduce liver fibrogenesis.

Antifibrotic Molecules with a Direct Effect on Myofibroblasts. We and others have shown that in different animal models of liver fibrosis, pentoxifylline, a methyl xanthine phosphodiesterase inhibitor, is able to reduce fibroproliferation and myofibroblastic differentiation and appears as a potential antifibrogenic drug (Desmoulière et al, 1999; Peterson, 1993; Raetsch et

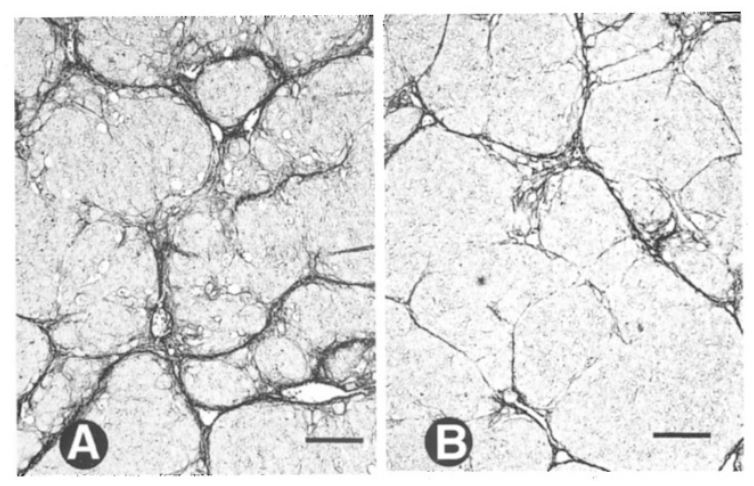

Figure 5.

Effect of 6-hydroxydopamine (OHDA) on liver fibrosis after $\mathrm{CCl}_{4}$ treatment for 6 weeks (Sirius red staining). (A) Rat treated with $\mathrm{CCl}_{4}$ alone. (B) Rat treated with $\mathrm{CCl}_{4}$ and OHDA. Scale bar $=200 \mu \mathrm{m}$. From Dubuisson et al (2002), with the kind permission of the publisher. 
al, 2002). (In France, pentoxifylline in association with tocopherol is now used in hepatitic $C$ treatment as an antifibrotic agent in a multicentric randomized clinical trial promoted by the Agence Nationale de Recherche sur le Sida; co-ordinator: S. Pol, Hôpital Necker, Paris, France.) It has been shown that $\alpha$ IFN decreases $\alpha$-SM actin expression by human hepatic stellate cells in culture (Mallat et al, 1995) and reduces liver fibrosis in non-A, non-B hepatitis (Guerret et al, 1999; Manabe et al, 1993). More recently, we have observed that transresveratrol (Godichaud et al, 2000), a grapevinederived polyphenol, shows antifibrotic activity, suggesting a useful action to prevent excessive scarring. Indeed, many botanicals including colchicine and silymarin, have been investigated for their antifibrotic potential, but mechanisms of action need to be further explored (review by Stickel et al, 2002).

\section{The Myofibroblastic Cells in Kidney Pathology}

Human Pathologies. Renal interstitial fibrosis is a major factor in progressive renal disease leading to expansion of the interstitial extracellular matrix, proliferation of fibroblastic cells, differentiation of myofibroblasts, and eventually contraction, collapse, and scarring of the kidney. The progression of tubulointerstitial fibrosis is in fact the best correlate of declining renal function (Hewitson and Becker, 1995). Tubulointerstitial fibrosis is a common endpoint of many renal diseases and is a feature of several experimental models of renal disease in animals.

The human renal diseases include those caused by infection as seen in pyelonephritis, in drug- or toxinrelated conditions such as cyclosporine A treatment, in immunologic diseases such as lupus nephritis, in transplant rejection, in $\lg A$ glomerulonephritis, in physical obstruction, and in a number of hereditary disorders such as polycystic kidney disease (for review, see Razzaque and Taguchi, 2002). Additionally, metabolic disorders leading to kidney disease such as diabetic nephropathy are also associated with tubulointerstitial fibrosis in addition to the glomerular changes that they cause, such as matrix expansion and glomerulosclerosis.

Animal Models of Tubulointerstitial Fibrosis: Mechanisms and Cells Involved. A number of animal models have been used to study cellular events leading to interstitial fibrosis, including ureteral ligation or obstruction, experimental infection (as a model of pyelonephritis), sub-total nephrectomy, and experimental diabetes induced with drugs such as streptozotocin.

As with many organs, the kidney possesses a population of fibroblasts that can become activated after injury and may transform into myofibroblasts. These cells are predominantly present around tubules in the kidney (Fig. 6); in the normal kidney, they are $\alpha$-SM actin negative. As with myofibroblasts present during wound repair in the skin, renal interstitial myofibroblasts are generally $\alpha$-SM actin positive but can rarely show other markers of muscle differentiation such as desmin. Other specific markers have also been suggested such as FSP-1, a putative marker of

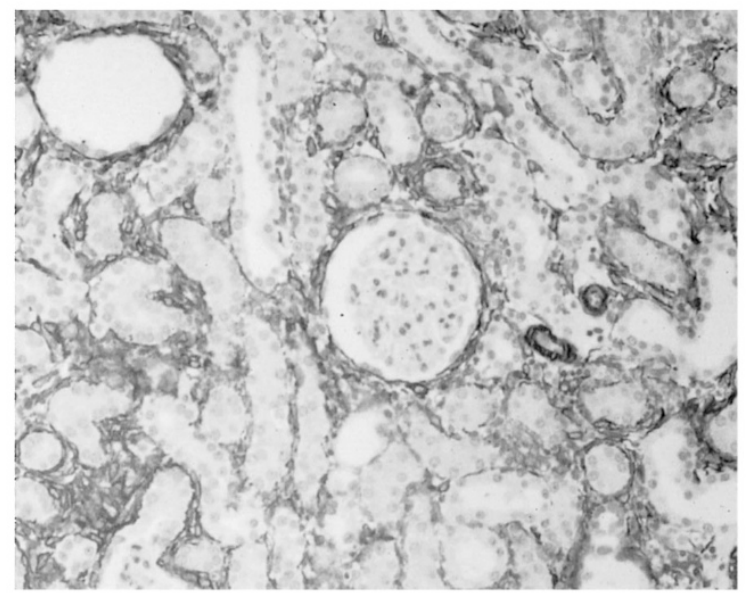

Figure 6.

$\alpha$-Smooth muscle (SM) actin staining in a rat kidney after unilateral ureteric obstruction. Peritubular fibroblasts, which are normally $\alpha$-SM actin negative, rapidly differentiate into $\alpha$-SM actin-expressing myofibroblasts. $\times 100$

interstitial myofibroblasts in the kidney, which is discussed further below (Strutz et al, 1995; Iwano et al, 2002).

The same growth factors that stimulate differentiation of myofibroblasts in the skin have been implicated in the transformation of renal fibroblasts that are $\alpha$-SM actin-negative to $\alpha$-SM actin-positive myofibroblasts. Much early work concentrated on TGF- $\beta$ as the major stimulus to transformation of resident fibroblasts to myofibroblasts (Horvath et al, 1996). Importantly, these growth factors contribute to fibrosis by causing increased extracellular matrix synthesis, collagen I and III in particular. Matrix deposition is favored also by the reduction in matrix metalloproteinases brought about by increased TGF- $\beta$ expression. Other factors that have been implicated include CTGF, TNF- $\alpha$, and angiotensin II (Goldschmeding et al, 2000; Gupta et al, 2000; Klahr et al, 1995). Angiotensin II involvement is suggested by data showing that angiotensin-converting enzyme inhibitors can inhibit fibrosis in the kidney (Ruiz-Ortega and Egido, 1997). In addition, studies with angiotensin receptor knockout animals show reduced fibrosis in the kidney of animals with experimental models of fibrosis such as ureteral obstruction (Ishidoya et al, 1995). These studies have generally suggested that angiotensin II acts through stimulation of TGF- $\beta$ rather than acting directly on interstitial cells. Along the same lines, angiotensinogen knockout animals show less renal fibrosis in response to injury (obstruction) with both collagen expression and tubular atrophy reduced (Fern et al, 1999). Angiotensin may be produced locally in the interstitium of the kidney allowing for a paracrine or autocrine stimulation of interstitial fibroblasts (Okada et al, 2002).

Many of the renal pathologies have an inflammatory component, and attraction of polymorphonuclear cells and monocytes/macrophages into the tissue provides another source of growth factors and cytokines capable of stimulating myofibroblast differentiation and proliferation, and extracellular matrix production. 
TGF- $\beta$ and CTGF are candidates for important roles in stimulating myofibroblast differentiation and extracellular matrix output. This is clear from studies showing increased TGF- $\beta$ expression in the kidney in fibrotic disorders and by studies that have localized the expression to the interstitium. The importance of TGF- $\beta$ as a stimulus to fibrosis can be shown by studies where inhibition of TGF- $\beta$ either with the matrix protein decorin (Peters et al, 1997) or by blocking its expression using antisense oligonucleotides have reduced the progression of fibrosis in experimental models (Akagi et al, 1996; Isaka et al, 2000). TGF- $\beta$ is also likely responsible for glomerular changes through actions on mesangial cell extracellular matrix secretion.

Apoptosis, as mentioned above, plays an important role in resolution of normal wound repair as the highly cellular granulation tissue recedes to leave a relatively acellular scar. In renal fibrosis significant numbers of apoptotic cells have been observed. These are largely inflammatory cells, though some tubular epithelial cells and relatively few interstitial cells may also undergo apoptosis. However, there may be, as in wound healing, a more significant loss of cells during the collapse phase, which is dependent on apoptosis of both tubular and interstitial cells. In obstructive models of kidney disease, tubular cell and interstitial cell apoptosis occurs resulting in atrophy (Lieberthal et al, 1998).

Origin of Renal Myofibroblasts. The origin of the myofibroblastic cells in tubulointerstitial fibrosis remains to some extent open to discussion. It was assumed previously that the origin of renal myofibroblasts was largely local, by recruitment, proliferation and differentiation of resident interstitial fibroblasts. However, there remains a possibility that circulating cells could contribute to the fibrotic lesion in the renal interstitium (Iwano et al, 2002). Additionally, recent evidence suggests local epithelial to mesenchymal transdifferentiation of tubular epithelial cells to myofibroblasts expressing $\alpha$-SM actin (Fan et al, 1999; Iwano et al, 2002; Oldfield et al, 2001). This has been demonstrated in experimental models where cells lose epithelial markers such as e-cadherin staining and acquire mesenchymal phenotypic markers such as vimentin and the myofibroblast marker $\alpha$-SM actin. Iwano et al (2002) have recently shown that fibroblasts expressing FSP1 and collagen I arise by epithelial to mesenchymal transformation during unilateral ureteric obstruction. In vitro studies of tubular epithelial cell lines have also added weight to the suggestion that this is possible and that this epithelial-mesenchymal transformation can be mediated by growth factors, in particular TGF- $\beta$ (Fan et al, 1999), and by other molecules such as advanced glycosylation endproducts, which are present in the plasma and tissue of diabetic humans and diabetic animals (Oldfield et al, 2001). CTGF itself has been shown to be associated with transdifferentiation of tubular epithelial cells to myofibroblasts in the remnant kidney model of fibrosis (Frazier et al, 2000).

Antifibrotic drugs have also been used to try to limit the extent of tubulointerstitial fibrosis in various animal models of renal disease, eg, the reduction in myofibroblasts and in extracellular matrix synthesis in the remnant kidney model brought about by mycophenolate mofetil treatment (Badid et al, 2000). A number of these compounds such as pentoxifylline, pirfenidone, and others have shown effects such as a reduction of fibroblast collagen synthesis in vitro (Hewitson et al, 2000).

\section{Conclusion}

The role of the myofibroblast as the main regulator of granulation tissue evolution and of fibrotic change development is presently well accepted (for review, see Tomasek et al, 2002). Figure 7 represents our working model on myofibroblastic differentiation and on its role during normal and pathologic tissue repair processes. The activity of myofibroblast depends on the combined action of cytokines and growth factors, extracellular matrix components, and, importantly, on the development of mechanical tension. Several aspects of myofibroblast regulation have been elucidated, but many remain to be explained, in particular the role of mechanical tension in the production and transmission of force. In this respect, it will be important to increase our knowledge of the composition of cell-to-matrix and cell-to-cell adhesion complexes, which appear to play an important role to connect myofibroblasts to extracellular connective tissue and among them. These studies should take into account the context of myofibroblast evolution and, in particular, the environment in which contraction phenomena takes place. Recent studies have shown that externally applied mechanical load can lead to the rapid and sequential induction of distinct extracellular matrix components in (myo)fibroblasts, indicating that extracellular matrix composition is adapted specifically to changes in load (Chiquet et al, 2003). These interactions between (myo)fibroblasts and extracellular matrix components, as well as the role of these interactions on cell behavior, have been particularly well described in three-dimensional collagen matrices (Grinnell, 2003; Grinnell et al, 2003).

The generation of force by the myofibroblast is starting to be elucidated, and further work on the mechanisms of stress fiber isometric contraction will furnish tools leading to the understanding not only of granulation tissue contraction mechanisms but also of the evolution of granulation tissue into a more permanent pathologic fibrotic tissue. As discussed above, the transmission of the isometric force produced by the myofibroblast is regulated by both stress fiber contractile activity and deposition and quality of extracellular matrix. Understanding of the interplay between these processes will be important to improve our knowledge of several physiologic and pathologic situations. In this respect it is noteworthy that a myofibroblastic nonfibrogenic phenotype has been described recently (Pan et al, 2002). This observation raises the possibility that formation and resumption of fibrosis are due at least in part to the prevalent action of a specific myofibroblastic phenotype. 


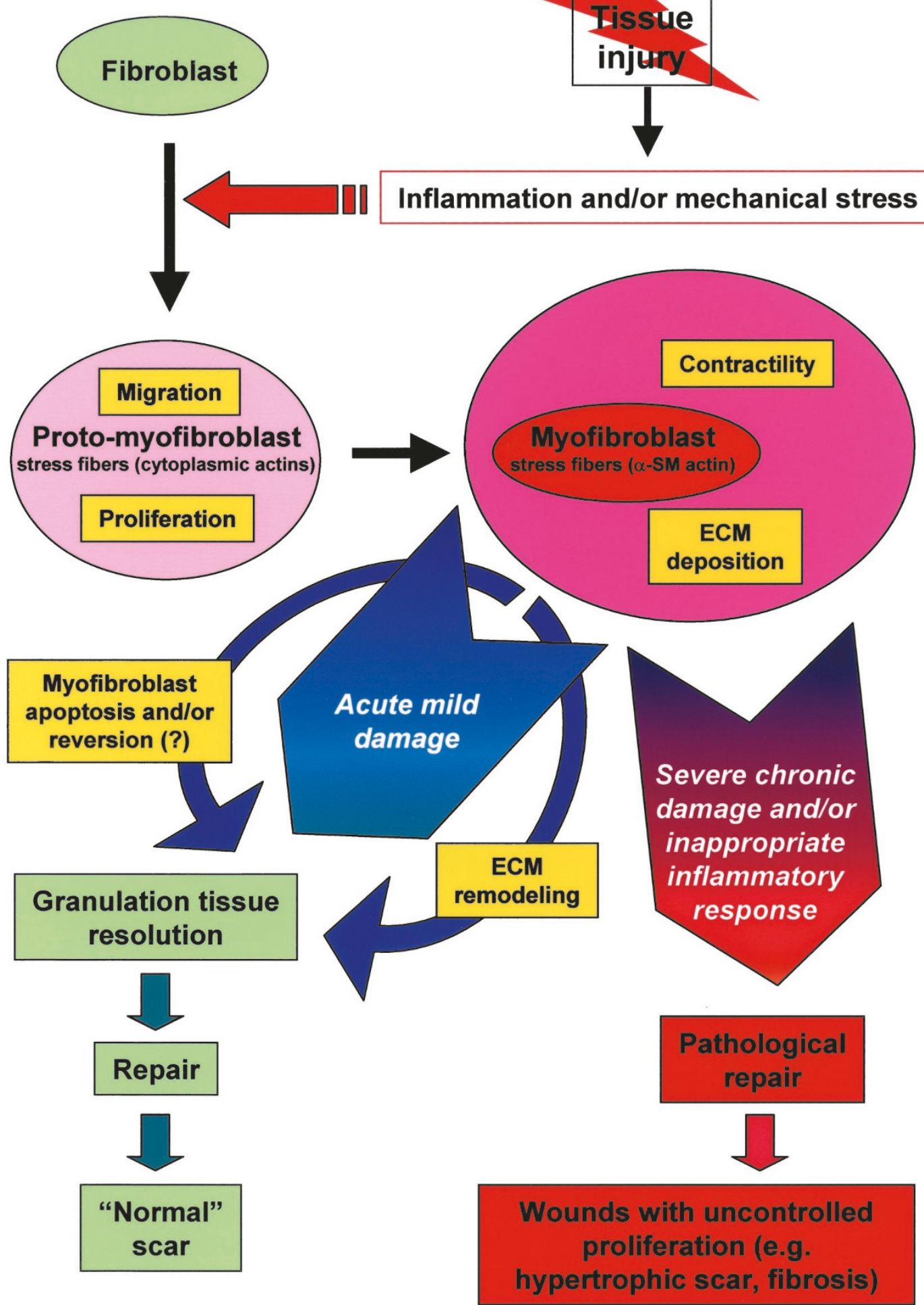

Figure 7.

A model for fibroblast-myofibroblast modulation during normal or excessive scar development. Proto-myofibroblasts express stress fibers containing cytoplasmic actins and develop focal adhesions. Myofibroblasts express stress fibers containing $\alpha$-smooth muscle (SM) actin and supermature focal adhesions. During granulation tissue resolution, the reversion of the myofibroblast phenotype to the fibroblast phenotype remains to be demonstrated. $E C M=$ extracellular matrix. 
Several agents have been shown to influence myofibroblast activity. Some of them, eg, interferons (Guerret et al, 1999; Mallat et al, 1995; Pittet et al, 1994), have shown a limited but clear effect on human fibrotic diseases. The description of the possibility that the $\mathrm{N}$-terminal peptide of $\alpha$-SM actin influences myofibroblast contraction and, albeit indirectly, collagen synthesis, may open a new perspective in the strategy toward regulation of fibrotic changes (Hinz et al, 2002). Many arguments now suggest major relationships between hemostasis and fibrosis, and activation of the coagulation cascade has been observed during pulmonary (Kotani et al, 1995) and liver (Papatheodoridis et al, 2003) fibrosis. Indeed, in addition to its role in hemostasis, thrombin exerts profibrotic effects via activation of the major thrombin receptor, proteaseactivated receptor-1. Thrombin is known to modulate myofibroblastic differentiation (Bogatkevich et al, 2001), and thrombin inhibition reduces extracellular matrix deposition and CTGF mRNA levels in bleomycin-induced pulmonary fibrosis (Howell et al, 2001). Thus, modulation of the coagulation cascade and of the profibrotic effects of coagulation proteases could interfere with fibrotic disorders. Finally, acting on TGF- $\beta$, a main factor involved in myofibroblastic differentiation and on some of its partners such as CTGF (Duncan et al, 1999) or endothelin-1 (Shao et al, 2003), may represent interesting tools to attenuate the "dark side" of tissue repair (Border and Ruoslahti, 1992). This nonexhaustive list of mechanisms acting on myofibroblast phenotype and activity illustrates different ways to develop new potential therapeutic strategies, including receptor antagonists, blocking antibodies, and antisense oligonucleotides, able to interfere with fibrogenesis.

In conclusion, during the past 40 years, the concept of granulation tissue contraction and fibrocontractive changes formation has been clarified in many aspects. Further work on the biology of the myofibroblast will definitively contribute to the understanding and the control of normal and pathologic connective tissue remodeling.

\section{Acknowledgements}

We would like to thank Dr. Tim Hewitson (Department of Nephrology, the Royal Melbourne Hospital, Australia) for helpful discussions regarding renal fibrosis.

\section{References}

Abe R, Donnelly SC, Peng T, Bucala R, and Metz CN (2001). Peripheral blood fibrocytes: Differentiation pathway and migration to wound sites. J Immunol 166:7556-7562.

Akagi Y, Isaka Y, Arai M, Kaneko T, Takenaka M, Moriyama T, Kaneda Y, Ando A, Orita Y, Kamada T, Ueda N, and Imai E (1996). Inhibition of TGF-beta 1 expression by antisense oligonucleotides suppressed extracellular matrix accumulation in experimental glomerulonephritis. Kidney Int 50:148155.
Akasawa $\mathrm{Y}$, Fujita K, Ishikawa $\mathrm{Y}$, Asuwa N, Inuzuka K, Ishihara $\mathrm{M}$, Ito $\mathrm{M}$, Masuda $\mathrm{T}$, Akishima $\mathrm{Y}$, Zhang $\mathrm{L}$, Ito $\mathrm{K}$, and Ishii $T$ (2001). Detection of apoptosis in keloids and a comparative study on apoptosis between keloids, hypertrophic scars and normal healed flat scars, and dermatofibroma. Wound Rep Reg 9:501-506.

Andrade ZA, Guerret S, and Fernandes AL (1999). Myofibroblasts in schistosomal portal fibrosis of man. Mam Inst Oswaldo Cruz 94:87-93.

Andreutti D, Gabbiani G, and Neuville P (1998). Early granulocyte-macrophage colony-stimulating factor expression by alveolar inflammatory cells during bleomycin-induced rat lung fibrosis. Lab Invest 78:1493-1502.

Arora PD and McCulloch CA (1994). Dependence of collagen remodelling on alpha-smooth muscle actin expression by fibroblasts. J Cell Physiol 159:161-175.

Athari A, Hanecke K, and Jungermann K (1994). Prostaglandin F2 alpha and D2 release from primary Ito cell cultures after stimulation with noradrenaline and ATP but not adenosine. Hepatology 20:142-148.

Badid C, Vincent M, McGregor B, Melin M, Hadj-Aissa A, Veysseyre $C$, Hartmann DJ, Desmoulière $A$, and Laville $M$ (2000). Mycophenolate mofetil reduces myofibroblast infiltration and collagen III deposition in rat remnant kidney. Kidney Int 58:51-61.

Ballardini G, Groff P, Badiali de Giorgi L, Schuppan D, and Bianchi FB (1994). Ito cell heterogeneity: Desmin-negative Ito cells in normal rat liver. Hepatology 19:440-446.

Bascom CC, Wolfshohl JR, Coffey RJ Jr, Madisen L, Webb NR, Purchio AR, Derynck R, and Moses HL (1989). Complex regulation of transforming growth factor beta 1 , beta 2 , and beta 3 mRNA expression in mouse fibroblasts and keratinocytes by transforming growth factors beta 1 and beta 2 . Mol Cell Biol 9:5508-5515.

Basson M and Burney R (1982). Defective wound healing in patients with paraplegia and quadriplegia. Surg Gynecol Obstr 155:9-12.

Beer HD, Gassmann MG, Munz B, Steiling H, Engelhardt F, Bleuel K, and Werner S (2000). Expression and function of keratinocyte growth factor and activin in skin morphogenesis and cutaneous wound repair. J Investig Dermatol Symp Proc $5: 34-39$

Beno DW, Espinal R, Edelstein BM, and Davis BH (1993). Administration of prostaglandin E1 analog reduces rat hepatic and Ito cell collagen gene expression and collagen accumulation after bile duct ligation injury. Hepatology 17: 707-714.

Bhunchet E and Wake K (1992). Role of mesenchymal cell populations in porcine serum-induced rat liver fibrosis. Hepatology 16:1452-1473.

Bioulac-Sage P, Blanc JF, Lepreux S, Balabaud C, Rosenbaum J, and Desmoulière A (2000). Cirrhosis: Forever? Gastroenterol Clin Biol 24:877-882.

Bioulac-Sage P, Lafon ME, Le Bail B, and Balabaud C (1988). Perisinusoidal and pit cells in liver sinusoids. In: BioulacSage $P$, and Balabaud $C$, editors. Sinusoids in human liver: Health and disease. Leiden: Kupffer Cell Foundation, 38-50.

Bioulac-Sage P, Lafon ME, Saric J, and Balabaud C (1990). Nerves and perisinusoidal cells in human liver. J Hepatol 10:105-112. 
Birns M, Masek B, and Auerbach O (1962). The effects of experimental acute biliary obstruction and release on the rat liver. A histochemical study. Am J Pathol 40:95-112.

Blomhoff R and Wake K (1991). Perisinusoidal stellate cells of the liver: Important roles in retinol metabolism and fibrosis. FASEB J 5:271-277.

Bogatkevich GS, Tourkina E, Abrams CS, Harley RA, Silver RM, Ludwicka-Bradley A (2003). Contractile activity and smooth muscle-

actin organization in thrombin-induced human lung myofibroblasts. Am J Physiol Lung Cell Mol Physiol 285:L334L343.

Bogatkevich GS, Tourkina E, Silver RM, and LudwickaBradley A (2001). Thrombin differentiates normal lung fibroblasts to a myofibroblast phenotype via the proteolytically activated receptor-1 and a protein kinase C-dependent pathway. J Biol Chem 276:45184-45192.

Boigk G, Stroedter L, Herbst H, Waldschmidt J, Riecken EO, and Schuppan D (1997). Silymarin retards collagen accumulation in early and advanced biliary fibrosis secondary to complete bile duct obliteration in rats. Hepatology 26:643649.

Border WA and Ruoslahti E (1992). Transforming growth factor-beta in disease: The dark side of tissue repair. J Clin Invest 90:1-7.

Bork P (1993). The modular architecture of a new family of growth regulators related to connective tissue growth factor. FEBS Lett 327:125-130.

Brown LF, Dubin D, Lavigne L, Logan B, Dvorak HF, and Van De Water L (1993). Macrophages and fibroblasts express embryogenic fibronectins during cutaneous wound healing. Am J Pathol 142:793-801.

Brown LF, Yeo KT, Berse B, Yeo TK, Senger DR, Dvorak HF, and van de Water $L$ (1992). Expression of vascular permeability factor (vascular endothelial growth factor) by epidermal keratinocytes during wound healing. J Exp Med 176: 1375-1379.

Buckingham ME, Alonso S, Barton P, Bugaisky G, Cohen A, Daubas P, Garner I, Minty A, Robert B, and Weydert A (1984). Actin and myosin genes, and their expression during myogenesis in the mouse. In: Davidson EH, and Firtel RA, editors. Molecular biology of development. New York: Liss AR, 275292.

Cameron GR and Prasad LBM (1960). Recovery from biliary obstruction after spontaneous restoration of the obstructed common bile-duct. J Path Bact 80:127-136.

Cass DL, Sylvester KG, Yang EY, Crombleholme TM, and Adzick NS (1997). Myofibroblast persistence in fetal sheep wounds is associated with scar formation. J Pediatr Surg 32:1017-1021.

Cassiman D and Roskams T (2002). Beauty is in the eye of the beholder: Emerging concepts and pitfalls in hepatic stellate cell research. J Hepatol 37:527-535.

Cassiman D, Libbrecht L, Desmet V, Denef C, and Roskams $T$ (2002). Hepatic stellate cell/myofibroblast subpopulations in fibrotic human and rat livers. J Hepatol 36:200-209.

Cassiman D, Roskams T, van Pelt J, Libbrecht L, Aertsen P, Crabbe T, Vankelecom H, and Denef C (2001). Alpha B-crystallin expression in human and rat hepatic stellate cells. J Hepatol 35:200-207.
Chiquet M, Renedo AS, Huber F, and Fluck M (2003). How do fibroblasts translate mechanical signals into changes in extracellular matrix production? Matrix Biol 22:73-80.

Cho JJ, Hocher B, Herbst H, Jia JD, Ruehl M, Hahn EG, Riecken EO, and Schuppan D (2000). An oral endothelin-A receptor antagonist blocks collagen synthesis and deposition in advanced rat liver fibrosis. Gastroenterology 118: 1169-1178.

Chodon T, Sugihara T, Igawa HH, Funayama E, and Furukawa $\mathrm{H}$ (2000). Keloid-derived fibroblasts are refractory to Fas-mediated apoptosis and neutralization of autocrine transforming growth factor- $\beta 1$ can abrogate this resistance. Am J Pathol 157:1661-1669.

Christen T, Verin V, Bochaton-Piallat M, Popowski Y, Ramaekers F, Debruyne P, Camenzind E, van Eys G, and Gabbiani $G$ (2001). Mechanisms of neointima formation and remodeling in the porcine coronary artery. Circulation 103: 882-888.

Clark LD, Clark RK, and Heber-Katz E (1998). A new murine model for mammalian wound repair and regeneration. Clin Immunol Immunopathol 88:35-45.

Costa AMA, Tuchweber B, Lamireau T, Yousef IM, Balabaud C, Rosenbaum J, and Desmoulière A (2003). Role of apoptosis in the remodeling of cholestatic liver injury following release of the mechanical stress. Virchows Arch 442:372380.

Costa AMA, Tuchweber B, Rubbia-Brandt L, Peyrol S, Chevallier M, Adham M, Gabbiani G, Rosenbaum J, and Desmoulière A (2001). Early activation of hepatic stellate cells and perisinusoidal extracellular matrix changes during ex vivo pig liver perfusion. J Submicrosc Cytol Pathol 33:321-340.

Darby I, Skalli O, and Gabbiani G (1990). Alpha-smooth muscle actin is transiently expressed by myofibroblasts during experimental wound healing. Lab Invest 63:21-29.

Darby IA, Bisucci T, Hewitson TD, and MacLellan DG (1997). Apoptosis is increased in a model of diabetes-impaired wound healing in genetically diabetic mice. Int $\mathrm{J}$ Biochem Cell Biol 29:191-200.

Darby IA, Bisucci T, Pittet B, Garbin S, Gabbiani G, and Desmoulière A (2002). Skin flap induced regression of granulation tissue correlates with reduced growth factor and increased metalloproteinase expression. J Pathol 197:117127.

Desmoulière A and Gabbiani G (1996). The role of the myofibroblast in wound healing and fibrocontractive diseases. In: Clark RAF, editor. The Molecular and Cellular Biology of Wound Repair, 2nd ed. New York: Plenum Press Corporation, 391-423.

Desmoulière A, Badid C, Bochaton-Piallat ML, and Gabbiani G (1997a). Apoptosis during wound healing, fibrocontractive diseases and vascular wall injury. Int J Biochem Cell Biol 29:19-30.

Desmoulière A, Darby I, Monte Alto Costa A, Raccurt M, Tuchweber B, Sommer P, and Gabbiani G (1997b). Extracellular matrix deposition, lysyl oxydase expression, and myofibroblastic differentiation during the initial stages of cholestatic fibrosis in the rat. Lab Invest 76:765-778.

Desmoulière A, Geinoz A, Gabbiani F, and Gabbiani G (1993). Transforming growth factor- $\beta 1$ induces $\alpha$-smooth muscle actin expression in granulation tissue myofibroblasts and in 
quiescent and growing cultured fibroblasts. J Cell Biol 122: 103-111.

Desmoulière A, Redard M, Darby I, and Gabbiani G (1995). Apoptosis mediates the decrease in cellularity during the transition between granulation tissue and scar. Am J Pathol 146:56-66.

Desmoulière A, Rubbia-Brandt L, Abdiu A, Walz T, MacieiraCoelho A, and Gabbiani G (1992a). $\alpha$-Smooth muscle actin is expressed in a subpopulation of cultured and cloned fibroblasts and is modulated by $\gamma$-interferon. Exp Cell Res 201: 64-73.

Desmoulière A, Rubbia-Brandt L, Grau G, and Gabbiani G (1992b). Heparin induces $\alpha$-smooth muscle actin expression in cultured fibroblasts and in granulation tissue myofibroblasts. Lab Invest 67:716-726.

Desmoulière A, Xu G, Costa AMA, Yousef IM, Gabbiani G, and Tuchweber B (1999). Effect of pentoxifylline on early proliferation and phenotypic modulation of fibrogenic cells in two rat models of liver fibrosis and on cultured hepatic stellate cells. J Hepatol 30:621-631.

Dranoff JA, Kruglov EA, Robson SC, Braun N, Zimmermann $\mathrm{H}$, and Sevigny $\mathrm{J}$ (2002). The ecto-nucleoside triphosphate diphosphohydrolase NTPDase2/CD39L1 is expressed in a novel functional compartment within the liver. Hepatology 36:1135-1144.

Dubuisson L, Desmoulière A, Decourt B, Ecade L, Bedin C, Boussarie L, Barrier L, Vidaud M, and Rosenbaum J (2002). Inhibition of liver fibrogenesis through noradrenergic antagonism. Hepatology 35:325-331.

Dubuisson L, Monvoisin A, Nielsen BS, Le Bail B, BioulacSage P, and Rosenbaum J (2000). Expression and cellular localization of the urokinase-type plasminogen activator and its receptor in human hepatocellular carcinoma. J Pathol 190:190-195.

Dugina V, Fontao L, Chaponnier C, Vasiliev J, and Gabbiani G (2001). Focal adhesion features during myofibroblastic differentiation are controlled by intracellular and extracellular factors. J Cell Sci 114:3285-3296.

Duncan MR, Frazier KS, Abramson S, Williams S, Klapper H, Huang X, and Grotendorst GR (1999). Connective tissue growth factor mediates transforming growth factor $\beta$-induced collagen synthesis: Down-regulation by cAMP. FASEB J 13:1774-1786.

Ehrlich HP, Desmouliere A, Diegelmann RF, Cohen IK, Compton CC, Garner WL, Kapanci Y, and Gabbiani G (1994). Morphological and immunochemical differences between keloid and hypertrophic scar. Am J Pathol 145:105-113.

Estes JM, Vande Berg JS, Adzick NS, MacGillivray TE, Desmouliere A, and Gabbiani G (1994). Phenotypic and functional features of myofibroblasts in sheep fetal wounds. Differentiation 56:173-181.

Eyden BP (1993). Brief review of the fibronexus and its significance for myofibroblastic differentiation and tumor diagnosis. Ultrastruct Pathol 17:611-622.

Fan JM, Ng YY, Hill PA, Nikolic-Paterson DJ, Mu W, Atkins $\mathrm{RC}$, and Lan HY (1999). Transforming growth factor- $\beta$ regulates tubular epithelial-myofibroblast transdifferentiation in vitro Kidney Int 56:1455-1467.

Faouzi S, Le Bail B, Neaud V, Boussarie L, Saric J, BioulacSage P, Balabaud C, and Rosenbaum J (1999). Myofibroblasts are responsible for collagen synthesis in the stroma of human hepatocellular carcinoma: An in vivo and in vitro study. J Hepatol 30:275-284.

Fern RJ, Yesko CM, Thornhill BA, Kim HS, Smithies O, and Chevalier RL (1999). Reduced angiotensinogen expression attenuates renal interstitial fibrosis in obstructive nephropathy in mice. J Clin Invest 103:39-46.

Folger PA, Zekaria D, Grotendorst G, and Masur SK (2001). Transforming growth factor-beta-stimulated connective tissue growth factor expression during corneal myofibroblast differentiation. Invest Ophthalmol Vis Sci 42:2534-2541.

Frazier K, Williams S, Kothapalli D, Klapper H, and Grotendorst GR (1996). Stimulation of fibroblast cell growth, matrix production, and granulation tissue formation by connective tissue growth factor. J Invest Dermatol 107:404-411.

Frazier KS, Paredes A, Dube P, and Styer E (2000). Connective tissue growth factor expression in the rat remnant kidney model and association with tubular epithelial cells undergoing transdifferentiation. Vet Pathol 37:328-335.

Friedman SL (1998). In: Schiff E, Sorrell M, and Maddrey W, editors. Diseases of the liver, $8^{\text {th }}$ ed. Philadelphia: LippincottRaven, 371-386.

Futakuchi M, Hirose M, Ogiso T, Kato K, Sano M, Ogawa K, and Shirai T (1999). Establishment of an in vivo highly metastatic rat hepatocellular carcinoma model. Jpn J Cancer Res 90:1196-1202.

Gabbiani G (1998). Evolution and clinical implications of the myofibroblast concept. Cardiovasc Res 38:545-548.

Gabbiani G, Ryan GB, and Majno G (1971). Presence of modified fibroblasts in granulation tissue and their possible role in wound contraction. Experientia 27:549-550.

Glaser S, LeSage G, Alvaro D, Chowdury U, Kanno N, Francis $H$, Eisel W, and Alpini G (1999). Ablation of the D2 dopaminergic innervation by intraportal injection of 6-hydroxydopamine (6-OHDA) reduces cholangiocyte proliferative and secretory activity in bile duct ligated (BDL) rats (Abstract). Hepatology 30:A1088.

Godichaud S, Krisa S, Couronné B, Dubuisson L, Mérillon JM, Desmoulière A, and Rosenbaum J (2000). Deactivation of cultured human liver myofibroblasts by trans-resveratrol, a grapewine-derived polyphenol. Hepatology 31:922-931.

Goldschmeding R, Aten J, Ito Y, Blom I, Rabelink T, and Weening JJ (2000). Connective tissue growth factor: Just another factor in renal fibrosis? Nephrol Dial Transplant 15:296-299.

Grillo HC (1963). Origin of fibroblasts in wound healing: An autoradiographic study of inhibition of cellular proliferation by local x-irradiation. Ann Surg 157:453-467.

Grinnell F (1994). Fibroblasts, myofibroblasts and wound contraction. J Cell Biol 124:401-404.

Grinnell F (2000). Fibroblast-collagen-matrix contraction: Growth-factor signalling and mechanical loading. Trends Cell Biol 10:362-365.

Grinnell F (2003). Fibroblast biology in three-dimensional collagen matrices. Trends Cell Biol 13:264-269.

Grinnell F, Ho CH, Tamariz E, Lee DJ, and Skuta G (2003). Dendritic fibroblasts in three-dimensional collagen matrices. Mol Biol Cell 14:384-395.

Grinnell F, Zhu M, Carlson MA, and Abrams JM (1999). Release of the mechanical tension triggers apoptosis of 
human fibroblasts in a model of regressing granulation tissue. Exp Cell Res 248:608-619.

Guerret S, Desmoulière A, Chossegros $P$, Costa AMA, Badid C, Trépo C, Grimaud JA, and Chevallier M (1999). Long-term administration of interferon- $\alpha$ in non-responder patients with chronic hepatitis C: Follow-up over 5 years of liver fibrosis. J Viral Hepatitis 6:125-133.

Gupta S, Clarkson MR, Duggan J, and Brady HR (2000). Connective tissue growth factor: potential role in glomerulosclerosis and tubulointerstitial fibrosis. Kidney Int 58:13891399.

Hall A (1998). Rho GTPases and the actin cytoskeleton. Science 279:509-514.

Hammel P, Couvelard A, O'Toole D, Ratouis A, Sauvanet A, Flejou JF, Degott C, Belghiti J, Bernades P, Valla D, Ruszniewski P, and Levy P (2001). Regression of liver fibrosis after biliary drainage in patients with chronic pancreatitis and stenosis of the common bile duct. N Engl J Med 344:418423.

Hewitson TD and Becker GJ (1995). Interstitial myofibroblasts in IgA glomerulonephritis. Am J Nephrol 15:111-117.

Hewitson TD, Martic M, Kelynack KJ, Pedagogos E, and Becker GJ (2000). Pentoxifylline reduces in vitro renal myofibroblast proliferation and collagen secretion. Am J Nephrol $20: 82-88$.

Higton DIR and James DW (1964). The force of contraction of full-thickness wounds of rabbit skin. Br J Surg 51:462-466.

Hinz B, Celetta G, Tomasek JJ, Gabbiani G, and Chaponnier C (2001a). $\alpha$-Smooth muscle actin expression upregulates fibroblast contractile activity. Mol Biol Cell 12:2730-2741.

Hinz B, Dugina V, Ballestrem C, Wehrle-Haller B, and Chaponnier C (2003). Alpha-smooth muscle actin is crucial for focal adhesion maturation in myofibroblasts. Mol Biol Cell 14:2508-2519.

Hinz B, Gabbiani G, and Chaponnier C (2002). The NH2terminal peptide of alpha-smooth muscle actin inhibits force generation by the myofibroblast in vitro and in vivo. J Cell Biol 157:657-663.

Hinz B, Mastrangelo D, Iselin CE, Chaponnier C, and Gabbiani $G$ (2001b). Mechanical tension controls granulation tissue contractile activity and myofibroblast differentiation. Am J Pathol 159:1009-1020.

Horvath LZ, Friess H, Schilling M, Borisch B, Deflorin J, Gold LI, Korc M, and Buchler MW (1996). Altered expression of transforming growth factor- $\beta \mathrm{s}$ in chronic renal rejection. Kidney Int 50:489-498.

Howell DC, Goldsack NR, Marshall RP, McAnulty RJ, Starke R, Purdy G, Laurent GJ, and Chambers RC (2001). Direct thrombin inhibition reduces lung collagen, accumulation, and connective tissue growth factor mRNA levels in bleomycininduced pulmonary fibrosis. Am J Pathol 159:1383-1395.

Iredale JP, Benyon RC, Pickering J, McCullen M, Northrop M, Pawley S, Hovell C, and Arthur MJ (1998). Mechanisms of spontaneous resolution of rat liver fibrosis. Hepatic stellate cell apoptosis and reduced hepatic expression of metalloproteinase inhibitors. J Clin Invest 102:538-549.

Isaka $\mathrm{Y}$, Tsujie M, Ando $\mathrm{Y}$, Nakamura $\mathrm{H}$, Kaneda $\mathrm{Y}$, Imai E, and Hori M (2000). Transforming growth factor-beta 1 antisense oligodeoxynucleotides block interstitial fibrosis in unilateral ureteral obstruction. Kidney Int 58:1885-1892.
Ishidoya S, Morrisey J, McCracken R, Reyes A, and Klahr S (1995). Angiotensin II receptor antagonist ameliorates renal tubulointerstitial fibrosis caused by unilateral ureteral obstruction. Kidney Int 47:1285-1294.

Ishihara $\mathrm{H}$, Yoshimoto $\mathrm{H}$, Fujioka M, Murakami R, Hirano A, Fujii T, Ohtsuru A, Namba H, and Yamashita S (2000). Keloid fibroblasts resist ceramide-induced apoptosis by overexpression of insulin-like growth factor I receptor. J Invest Dermatol 115:1065-1071.

Iwano M, Plieth D, Danoff TM, Xue C, Okada H, and Neilson EG (2002). Evidence that fibroblasts derive from epithelium during tissue fibrosis. J Clin Invest 110:341-350.

Jancso N, Jancso-Gabor A, and Szolcsanyl J (1967). Direct evidence for neurogenic inflammation and its prevention by denervation and by pretreatment with capsaicin. $\mathrm{Br} \mathrm{J}$ Pharmacol 51:138-151.

Johnson P and Doll S (1984). Dermal nerves in human diabetic subjects. Diabetes 33:244-250.

Juliano RL and Haskill S (1993). Signal transduction from the extracellular matrix. J Cell Biol 120:577-585.

Kalka C, Masuda H, Takahashi T, Gordon R, Tepper O, Gravereaux E, Pieczek A, Iwaguro H, Hayashi S-I, Isner JM, and Asahara T (2000). Vascular endothelial growth factor 165 gene transfer augments circulating endothelial progenitor cells in human subjects. Circ Res 86:1198-1202.

Kim LR, Whelpdale K, Zurowski M, and Pomeranz B (1998). Sympathetic denervation impairs epidermal healing in cutaneous wounds. Wound Rep Reg 6:194-201.

Kinnman N, Francoz C, Barbu V, Wendum D, Rey C, Hultcrantz R, Poupon R, and Housset C (2003). The myofibroblastic conversion of peribiliary fibrogenic cells distinct from hepatic stellate cells is stimulated by platelet-derived growth factor during liver fibrogenesis. Lab Invest 83:163-173.

Kishimoto S (1984). The regeneration of substance-P containing nerve fibers in the process of burn wound healing in the guinea pig skin. J Invest Dermatol 83:219-223.

Klahr S, Ishidoya S, and Morrisey J (1995). Role of angiotensin II in the tubulointerstitial fibrosis of obstructive nephropathy. Am J Kidney Dis 26:141-146.

Knittel T, Kobold D, Piscaglia F, Saile B, Neubauer K, Mehde M, Timpl R, and Ramadori G (1999a). Localization of liver myofibroblasts and hepatic stellate cells in normal and diseased rat livers: Distinct roles of (myo-)fibroblast subpopulations in hepatic tissue repair. Histochem Cell Biol 112:387401.

Knittel T, Kobold D, Saile B, Grundmann A, Neubauer K, Piscaglia F, and Ramadori G (1999b). Rat liver myofibroblasts and hepatic stellate cells: Different cell populations of the fibroblast lineage with fibrogenic potential. Gastroenterology 117:1205-1221.

Kotani I, Sato A, Hayakawa H, Urano T, Takada Y, and Takada A (1995). Increased procoagulant and antifibrinolytic activities in the lungs with idiopathic pulmonary fibrosis. Thromb Res 77:493-504.

Kothapalli D, Frazier KS, Welply A, Segarini PR, and Grotendorst GR (1997). Transforming growth factor beta induces anchorage-independent growth of NRK fibroblasts via a connective tissue growth factor-dependent signaling pathway. Cell Growth Differ 8:61-68. 
Le Bail B, Faouzi S, Boussarie L, Guirouilh J, Blanc JF, Carles J, Bioulac-Sage P, Balabaud C, and Rosenbaum J (1999). Osteonectin/SPARC is overexpressed in human hepatocellular carcinoma. J Pathol 189:46-52.

Leferovich JM and Heber-Katz E (2002). The scarless heart. Semin Cell Dev Biol 13:327-333.

LeSage G, Alvaro D, Benedetti A, Glaser S, Marucci L, Baiocchi L, Eisel W, Caligiuri A, Phinizy JL, Rodgers R, Francis H, and Alpini G (1999). Cholinergic system modulates growth, apoptosis, and secretion of cholangiocytes from bile duct-ligated rats. Gastroenterology 117:191-199.

Lieberthal W, Koh JS, and Levine JS (1998). Necrosis and apoptosis in acute renal failure. Semin Nephrol 18:505-518.

Liu M, Warn JD, Fan Q, and Smith PG (1999). Relationship between nerves and myofibroblasts during cutaneous wound healing in the developing rat. Cell Tissue Res 297:423-433.

Loukianov E, Loukianova T, and Periasamy M (1997). Myosin heavy chain isoforms in smooth muscle. Comp Biochem Physiol B Biochem Mol Biol 117:13-18.

Luo S, Benathan M, Raffoul W, Panizzon RG, and Egloff DV (2001). Abnormal balance between proliferation and apoptotic cell death in fibroblasts derived from keloid lesions. Plast Reconstructive Surg 107:87-96.

MacDonald RA (1959). Origin of fibroblasts in experimental healing wounds: Autoradiographic studies using tritiated thymidine. Surgery 46:376-382.

Machesky LM and Hall A (1996). Rho: A connection between membrane receptor signalling and the cytoskeleton. Trends Cell Biol 6:304-310.

Machesney M, Tidman N, Waseem A, Kirby L, and Leigh I (1998). Activated keratinocytes in the epidermis of hypertrophic scars. Am J Pathol 152:1133-1141.

Maggi CA (1997). The effects of tachykinins on inflammatory and immune cells. Regul Pept 70:75-90.

Majno G, Gabbinai G, Hirschel BJ, Ryan GB, and Statkov PR (1971). Contraction of granulation tissue in vitro: Similarity to smooth muscle. Science 173:548-550.

Mallat A, Preaux AM, Blazejewski S, Rosenbaum J, Dhumeaux D, and Mavier P (1995). Interferon alfa and gamma inhibit proliferation and collagen synthesis of human Ito cells in culture. Hepatology 21:1003-1010.

Mallat A, Préaux AM, Serradeil-Le Gal C, Raufaste D, Gallois C, Brenner DA, Bradham C, Maclouf J, lourgenko V, Fouassier L, Dhumeaux D, Mavier P, and Lotersztajn S (1996). Growth inhibitory properties of endothelin-1 in activated human hepatic stellate cells: a cyclic adenosine monophosphate-mediated pathway. Inhibition of both extracellular signal-regulated kinase and c-Jun kinase and upregulation of endothelin B receptors. J Clin Invest 98:27712778.

Manabe N, Chevallier M, Chossegros P, Causse X, Guerret S, Trépo C, and Grimaud JA (1993). Interferon- $\alpha 2 b$ therapy reduces liver fibrosis in chronic non-A, non-B hepatitis: $A$ quantitative histological evaluation. Hepatology 18:13441349.

Molitoris BA (1997). Putting the actin cytoskeleton into perspective: Pathophysiology of ischemic alterations. Am J Physiol 272:F430-F433.

Monvoisin A, Bisson C, Si-Tayeb K, Balabaud C, Desmoulière $A$, and Rosenbaum $\mathrm{J}$ (2002). Involvement of matrix metalloproteinase type-3 in hepatocyte growth factorinduced invasion of human hepatocellular carcinoma cells. Int J Cancer 97:157-162.

Monvoisin A, Neaud V, De Lédinghen V, Dubuisson L, Balabaud C, Bioulac-Sage $P$, Desmoulière $A$, and Rosenbaum J (1999). Direct evidence that hepatocyte growth factor-induced invasion of hepatocellular carcinoma cells is mediated by urokinase. J Hepatol 30:511-518.

Moulin V, Tam BY, Castilloux G, Auger FA, O'ConnorMcCourt MI, Philip A, and Germain L (2001). Fetal and adult human skin fibroblasts display intrinsic differences in contractile capacity. J Cell Physiol 188:211-220.

Murphy FR, Issa R, Zhou X, Ratnarajah S, Nagase H, Arthur MJ, Benyon C, and Iredale JP (2002). Inhibition of apoptosis of activated hepatic stellate cells by tissue inhibitor of metalloproteinase- 1 is mediated via effects on matrix metalloproteinase inhibition: Implications for reversibility of liver fibrosis. J Biol Chem 277:11069-11076.

Neaud V, Faouzi S, Guirouilh J, Le Bail B, Balabaud C, Bioulac-Sage P, and Rosenbaum J (1997). Human hepatic myofibroblasts increase invasiveness of hepatocellular carcinoma cells: Evidence for a role of hepatocyte growth factor. Hepatology 26:1458-1466.

Neaud V, Hisaka T, Monvoisin A, Bedin C, Balabaud C, Foster DC, Desmouliere A, Kisiel W, and Rosenbaum J (2000). Paradoxical pro-invasive effect of the serine proteinase inhibitor tissue factor pathway inhibitor-2 on human hepatocellular carcinoma cells. J Biol Chem 275:3556535569.

Nilsson J, Euler AM, and Dalsgaard CJ (1986). Stimulation of connective tissue cell growth by substance $\mathrm{P}$ and substance K. Nature 315:61-63.

Okada H, Inoue T, Kanno Y, Kobayashi T, Watanabe Y, Kopp JB, Carey RM, and Suzuki H (2002). Interstitial fibroblast-like cells express renin-angiotensin system components in a fibrosing murine kidney. Am J Pathol 160:765-772.

Okada H, Strutz F, Danoff T, and Neilson EG (1996). Possible pathogenesis in renal fibrosis. Kidney Int 49:S37-S39.

Oldfield MD, Bach LA, Forbes JM, Nikolic-Paterson D, McRobert A, Thallas V, Atkins T, Jerums G, and Cooper ME (2001). Advanced glycation end products cause epithelialmyofibroblast transdifferentiation via the receptor for advanced glycation end products (RAGE). J Clin Invest 108: 1853-1863.

Olivari N, Schrudde J, and Wahle H (1972). The surgical treatment of bedsores in paraplegics. Plast Reconst Surg 50:477-482.

Pan D, Zhe X, Jakkaraju S, Taylor GA, and Schuger L (2002). P311 induces a TGF-beta1-independent, nonfibrogenic myofibroblast phenotype. J Clin Invest 110:1349-1358.

Papatheodoridis GV, Papakonstantinou E, Andrioti E, Cholongitas E, Petraki K, Kontopoulou I, and Hadziyannis SJ (2003). Thrombotic risk factors and extent of liver fibrosis in chronic viral hepatitis. Gut 52:404-409.

Peters H, Noble NA, and Border WA (1997). Transforming growth factor-beta in human glomerular injury. Curr Opin Nephrol Hypertens 6:389-393.

Peterson TC (1993). Pentoxifylline prevents fibrosis in an animal model and inhibits platelet-derived growth factordriven proliferation of fibroblasts. Hepatology 17:486-493. 
Pinzani M (1995). Hepatic stellate (ITO) cells: Expanding roles for a liver-specific pericyte. J Hepatol 22:700-706.

Pittet B, Rubbia-Brandt L, Desmoulière A, Sappino AP, Roggero P, Guerret S, Grimaud JA, Lacher R, Montandon D, and Gabbiani $G$ (1994). Action of $\gamma$-interferon on the clinical and biologic evolution of hypertrophic scars and Dupuytren's disease: An open pilot study. Plast Reconstr Surg 93:12241235.

Raats JMH and Bloemendal H (1992). The role of protein domains in the assembly process of intermediate filaments. Progr Nucleic Acid Res Mol Biol 43:67-86.

Raetsch C, Jia JD, Boigk G, Bauer M, Hahn EG, Riecken EO, and Schuppan D (2002). Pentoxifylline downregulates profibrogenic cytokines and procollagen I expression in rat secondary biliary fibrosis. Gut 50:241-247.

Razzaque MS and Taguchi T (2002). Cellular and molecular events leading to renal tubulointerstitial fibrosis. Med Electron Microsc 35:68-80.

Ronnov-Jessen $L$ and Petersen OW (1993). Induction of $\alpha$-smooth muscle actin by transforming growth factor- $\beta 1$ in quiescent human breast gland fibroblasts. Implications for myofibroblast generation in breast neoplasia. Lab Invest 68:696-707.

Ross R, Everett NB, and Tyler R (1970). Wound healing and collagen formation. VI. The origin of the wound fibroblast studied in parabiosis. J Cell Biol 44:645-654.

Rubbia-Brandt L, Mentha G, Desmoulière A, Costa AMA, Giostra E, Molas G, Enzan H, and Gabbiani G (1997). Hepatic stellate cells reversibly express $\alpha$-smooth muscle actin during acute hepatic ischemia. Transplant Proc 29:2390-2395.

Rubbia-Brandt L, Sappino AP, and Gabbiani G (1991). Locally applied GM-CSF induces the accumulation of $\alpha$-smooth muscle actin containing myofibroblasts. Virchows Arch [B] Cell Pathol 60:73-82.

Rubin E, Hutterer F, and Popper H (1968). Experimental hepatic fibrosis without hepatocellular regeneration. Am J Pathol 52:111-119.

Ruiz-Ortega M and Egido J (1997). Angiotensin II modulates cell growth-related events and synthesis of matrix proteins in renal interstitial fibroblasts. Kidney Int 52:1497-1510.

Sappino SP, Schürch W, and Gabbiani G (1990). Differentiation repertoire of fibroblastic cells: Expression of cytoskeletal proteins as marker of phenotypic modulations. Lab Invest 63:144-161.

Sedlaczek N, Jia JD, Bauer M, Herbst H, Ruehl M, Hahn EG, and Schuppan D (2001). Proliferating bile duct epithelial cells are a major source of connective tissue growth factor in rat biliary fibrosis. Am J Pathol 158:1239-1244.

Schiaffino S and Reggiani C (1996). Molecular diversity of myofibrillar proteins: Gene regulation and functional significance. Physiol Rev 76:371-423.

Schmitt-Gräff A, Desmoulière A, and Gabbiani G (1994). Heterogeneity of myofibroblast phenotypic features: An example of fibroblastic cell plasticity. Virchows Arch 425:3-24.

Schürch W, Seemayer T, and Gabbiani G (1998). The myofibroblast. A quarter century after its discovery. Am J Surg Pathol 22:141-147.

Serini G and Gabbiani G (1999). Mechanisms of myofibroblast activity and phenotypic modulation. Exp Cell Res 250:273-283.
Serini G, Bochaton-Piallat ML, Ropraz P, Geinoz A, Borsi L, Zardi L, and Gabbiani G (1998). The fibronectin domain ED-A is crucial for myofibroblastic phenotype induction by transforming growth factor-beta1. J Cell Biol 142:873-881.

Shao R, Shi Z, Gotwals PJ, Koteliansky VE, George J, and Rockey DC (2003). Cell and molecular regulation of endothelin-1 production during hepatic wound healing. Mol Biol Cell 14:2327-2341.

Singer II, Kawka DW, Kazazis DM, and Clark RAF (1984). In vivo codistribution of fibronectin and actin fibers in granulation tissue: Immunofluorescence and electron microscope studies of the fibronexus at the myofibroblast surface. J Cell Biol 98:2091-2106.

Slott PA, Liu MH, and Tavoloni N (1990). Origin, pattern, and mechanism of bile duct proliferation following biliary obstruction in the rat. Gastroenterology 99:466-477.

Song IS, Bunnett NW, Olerud JE, Harten B, Steinhoff M, Brown JR, Sung KJ, Armstrong CA, and Ansel JC (2000). Substance $P$ induction of murine keratinocyte PAM 212 interleukin 1 production is mediated by the neurokinin 2 receptor (NK-2R). Exp Dermatol 9:42-52.

Stickel F, Brinkhaus B, Krahmer N, Seitz HK, Hahn EG, and Schuppan D (2002). Antifibrotic properties of botanicals in chronic liver disease. Hepatogastroenterology 49:1102-1108.

Strutz F, Okada H, Lo CW, Danoff T, Carone RL, Tomaszewski JE, and Neilson EG (1995). Identification and characterization of a fibroblast marker FSP1. J Cell Biol 130:393-405.

Sztark F (1986). Perisinusoidal cells in patients with normal liver histology. A morphological study. J Hepatol 2:358-369.

Teofoli P, Barduagni S, Ribuffo M, Campanella A, De Pita O, and Puddu $P$ (1999). Expression of Bcl-2, p53, c-jun and $\mathrm{c}$-fos protooncogenes in keloids and hypertrophic scars. $J$ Dermatologocial Sci 22:31-37.

Tomasek JJ, Gabbiani G, Hinz B, Chaponnier C, and Brown RA (2002). Myofibroblasts and mechano-regulation of connective tissue remodelling. Nat Rev Mol Cell Biol 3:349-363.

Tuchweber B, Desmoulière A, Bochaton-Piallat ML, RubbiaBrandt L, and Gabbiani G (1996). Proliferation and phenotypic modulation of portal fibroblasts in the early stages of cholestatic fibrosis in the rat. Lab Invest 74:265-278.

Uchio K, Tuchweber B, Manabe N, Gabbiani G, Rosenbaum $J$, and Desmoulière A (2002). Cellular retinol-binding protein-1 expression and modulation during in vivo and in vitro myofibroblastic differentiation of rat hepatic stellate cells and portal fibroblasts. Lab Invest 82:619-628.

Ueno T and Tanikawa K (1997). Intralobular innervation and lipocyte contractility in the liver. Nutrition 13:141-148.

Van der Loop FT, Gabbiani G, Kohnen G, Ramaekers FC, and van Eys GJ (1997). Differentiation of smooth muscle cells in human blood vessels as defined by smoothelin, a novel marker for the contractile phenotype. Arterioscler Thromb Vasc Biol 17:665-671.

Van der Loop FT, Schaart G, Timmer ED, Ramaekers FC, and van Eys GJ (1996). Smoothelin, a novel cytoskeletal protein specific for smooth muscle cells. J Cell Biol 134:401-411.

Vandekerckhove $\mathrm{J}$ and Weber K (1978). Mammalian cytoplasmic actins are the products of at least two genes and differ in primary structure in at least 25 identified positions from skeletal muscle actins. Proc Natl Acad Sci USA 75: 1106-1110. 
Vyalov S, Desmoulière A, and Gabbiani G (1993). GM-CSFinduced granulation tissue formation: Relationships between macrophage and myofibroblast accumulation. Virchows Arch [B] Cell Pathol 63:231-239.

Wallengren J (1997). Vasoactive peptides in the skin. J Invest Dermatol Symp Proc 2:49-55.

Werner S, Peters KG, Longaker MT, Fuller-Pace F, Banda MJ, and Williams LT (1992). Large induction of keratinocyte growth factor expression in the dermis during wound healing. Proc Natl Acad Sci USA 89:6896-6900.

Wysocki AB, Staiano-Coico L, and Grinnell F (1993). Wound fluid from chronic leg ulcers contains elevated levels of metalloproteinases MMP-2 and MMP-9. J Invest Dermatol 101:64-68.

Xu G, Redard M, Gabbiani G, and Neuville P (1997). Cellular retinol-binding protein-1 is transiently expressed in granulation tissue fibroblasts and differentially expressed in fibroblasts cultured from different organs. Am J Pathol 151:17411749 .
Yamada KM and Clark RAF (1996). Provisional matrix. In: Clark RAF, editor. The molecular and cellular biology of wound repair, 2nd ed. New York: Plenum Press Corporation, 51-93.

Zhang K, Rekhter MD, Gordon D, and Phan SH (1994). Myofibroblasts and their role in lung collagen gene expression during pulmonary fibrosis. A combined immunohistochemical and in situ hybridization study. Am J Pathol 145: $114-125$.

Ziche M, Morbidelli L, Pacini M, Geppetti P, Alessandri G, and Maggi CA (1990). Substance P stimulates neovascularization in vivo and proliferation of cultures epithelial cells. Microvasc Res 40:264-278. 